\title{
Süpervizör, Terapist ve Hasta Üçlüsünde Terapötik İttifak ve Etkileyen Faktör Olarak Şema Kavramı: Bir Vaka Üzerinden Analiz*
}

\author{
Bahar Köse Karaca \\ İstanbul Arel Üniversitesi
}

\begin{abstract}
Özet
Yapılan çalışmanın hedefi Young şema alanlarının, Young uyumsuz baş etme biçimlerinin, Young ebeveynlik biçimlerinin Süpervizör A, Terapist B ve Hasta C arasındaki terapötik ittifakını ölçmekti. Bu vaka çalışması için, katılımcılar bir süpervizör (klinik psikoloji doktora öğrencisi), bir terapist (klinik psikoloji yüksek lisans öğrencisi) ve bir hastadan (AYNA klinik psikoloji ünitesine başvuran) oluşmaktaydı. Araştırmada, terapötik ittifakı ölçmek için niteliksel (araştırmacı tarafindan geliştirilen açık uçlu soru formu ve ilişkisel halkalar) ve niceliksel (terapötik ittifak ölçekleri/süpervizör-terapist formları ve terapist-hasta formları) olmak üzere iki farklı ölçüm biçimi kullanıldı. Sonuçlara göre, Young erken yaş dönemi uyumsuz șemaları, Young baş etme biçimleri, Young ebeveynlik biçimleri ile süpervizörler, terapistler ve hastaların terapötik ittifakları arasında bir ilişki olduğu tespit edildi. Çıkan sonuçlar Şema Teorisi çerçevesinde tartışıldı.
\end{abstract}

Anahtar Kelimeler: Şema Teori, Terapötik İttifak, Süpervizyon, Psikoterapi

* Bu çalışma, Şema Terapi Kongresi’nde (İstanbul, 2014) genel hatları ile sunulmuştur. 


\section{Terapötik İttifak Kavramı ve Etkileyen Faktörler}

Yapılan araştırmalara göre, kullanılan terapi yaklaşımları, yöntemler ve psikolojik semptomlar sabit tutulsa bile, psikoterapilerin etkileri her zaman aynı olmamaktadır. Literatürde, bu durum için farklı açıklamalar mevcuttur. Psikoterapide kullanılan terapi yaklaşımı, terapistin eğitimi ve deneyimi, hastanın psikopatolojisi, seansların sıklığı ve hastaların tedavi için ne derecede motive olduğu sonuçları etkileyen faktörler arasındadır (Crits-Christoph ve ark., 1991; McCarthy ve Frieze, 1999; McCoy Lynch, 2012). Bunların yanı sıra, dikkat çeken bir diğer faktör şüphesiz ki terapötik ilişkidir. Literatürde, terapötik ilişkinin doğrudan mı yoksa dolaylı mı etkisi olduğu hala tartışma konusuyken, hasta ve terapist arasındaki ilişkinin iyileştiriciliği ciddi kabul görmektedir (Elvins ve Green, 2008; Gelso ve Carter, 1985; Gelso ve Carter, 1994; Horvath, Del Re, Flückiger, ve Symonds, 2011; Huppert ve ark., 2014; Priebe ve McCabe, 2006). Özellikle, terapi ilişkisinde yaşanan sıkıntıların fark edilmesi ve bu sıkıntıların aşılarak kaliteli bir terapötik ittifak yaratmak çabası hastanın psikoterapi sürecinde değişim yaşamasına önemli derecede katkı sağlamaktadır (Safran, 1993). Diğer taraftan, birçok araştırmacı psikoterapi sürecinde terapötik ittifakın önemini kabul ederken, terapötik ittifakın kavramsal tanımı ve nasıl ölçülebileceği henüz tartışma konusudur. Bununla birlikte, terapötik ittifakı analiz etmek, ölçmek ve kontrol etmek için, farklı yaklaşımlardan araştırmacılar hangi faktörlerin terapötik ittifakı etkilediği üzerine tartışma yürütmeye devam etmektedir.

Tarihsel bağlamda, terapötik ittifak kavramıyla ilgili ilk çalışmalar psikodinamik kurama aittir. Terapi içerisindeki ilişkinin önemine ilk kez Freud (1912/1913) dikkatleri çekmiştir. Freud (1913) yazılarında hastalarının duygularına ve doktorlarına olan bağlanmasına odaklanmış ve buna bağlı olarak aktarım ve karşıaktarım kavramlarını ortaya atmıştır. Freud' dan sonra daha birçok araştırmacı kendi kavramları ile terapötik ilişkinin önemine dikkat çekmiştir (Anderson ve Anderson, 1962; Baillargeon, Cote ve Douville, 2012; Barrett-Lennard, 1962/1978/1986; Curtis, 1979; Frank ve Frank, 1991; Frieswyk ve ark.,1986; Greenson, 1965; Hayes, 1998; Hougaard, 1994; Luborsky, 1976; Luborsky, Singer ve Luborsky, 1975; Orlinsky ve Howard, 1975; Rogers, 1957; Smith ve Gloss, 1977; Sterba, 1934; Zetzel, 1956). Ancak literatürde, bu kavramlar arasında en çok kabul gören ve kullanılan Bordin'in terapötik ittifak kavramı olmuştur (Gelso ve Carter, 1985; Greenson, 1967; Horvath ve Greenberg, 1989; Patton, 1984). Bordin'e göre (1979), terapötik ilişki hangi yaklaşımın kullanıldığına bağlı olmaksızın şımdi ve burada terapist ve hasta arasında tedavinin bütün biçimlerini kapsayan ilişkidir. Ayrıca terapötik ilişsi hem terapistin hem de hastanın ortak katılımından oluşan amaç, hedef ve duygusal bağ boyutlarından oluşmaktadır. Bu çalışmada da Bordin'in kavramı kullanılmıştır.

Terapötik ilişkinin öneminin anlaşılması ve kavramsallaştırma çalışmalarından sonra bu kavramların nasıl ölçüleceği literatür için bir diğer tartışma konusu olmuştur. Birçok araştırmacı çeşitli ölçekler geliştirmiştir (örn. Anderson ve Anderson, 1962; Barrett-Lennard, 1962; Stone ve Shertzer; 1965; Orlinsky ve Howard; 1966). Bu ölçeklerden ampirik olarak güçlü olmas1 nedeniyle en çok kullanılanlardan biri Horvath ve Greenberg'in (1989), Bordin'in (1979) amaç, hedef ve duygusal bağ odaklı terapötik ilişki kavramını ölçmek için oluşturulan Terapötik İttifak Ölçeğidir. Bu çalışmada da nicel yöntem olarak bu ölçek kullanılmıştır. Ancak, terapötik ilişkinin ölçümü ile ilgili tartışmalar ölçüm araçlarının kısıtlılıkları üzerine devam etmektedir. Bunlardan 
bazıları, terapötik ittifakın kavramsallaştırılmasında ortak bir görüşün olmaması, ölçeklerin genç yetişkinleri ölçmekte yetersiz kalması, kavramın karmaşık bir yapıya sahip olması ve nicel ölçümlerin ilişkinin bütününü ölçmekte yetersiz kalmasıdır (Elvins ve Green, 2008; Eugster ve Wampold, 1996; Green, Imre, Frances, Begum ve Gannon, 2001; Kelly, 1997). Tüm bu kısıtlılıklardan yola çıkarak, bu çalışmada terapötik ittifak için nitel ve projektif bir ölçek geliştirilmiştir.

Literatürdeki kavramsallaştırma ve ölçme çalışmalarından sonra, bir diğer tartışma konusu terapötik ittfakı nelerin etkiliyor olduğudur. Bununla ilgili terapi yaklaşımlarından farklı açıklamalar yapılmıştır (örn. Beck, Rush, Shaw ve Emery, 1979; Elliott, Watson, Goldman ve Greenberg, 2004; Freud, 1912; Hinshelwood, Robinson ve Zarate, 2006; Mayers ve Hayes, 2006; Sullivan, 1953; Safran ve Muran, 2000). Bu yaklaşımlardan en çok göze çarpan ise Şema Teori'nin açıklamaları olmuştur (Young, 1999). Şema Teori'ye göre hem terapistin hem de hastanın çocukluktan getirdiği erken yaş dönemi uyumsuz şemaları, ebeveyn kökeni, kaçınma ve telafi baş etme süreçleri terapötik ilişkiyi etkilemektedir. Şema Teori’ye göre (Young, 1999), beş şema alanı altında (ayrılma ve dişlanma/reddedilme, zedelenmiş özerklik ve performans, zedelenmiş sınırlar, başkalarına yönelimlilik, aşırı tetikte olma ve baskılama) toplam on sekiz erken yaş dönemi uyumsuz şeması vardır (terk edilme, güvensizlik/istismar edilme, duygusal yoksunluk, kusurluluk/utanç, sosyal izolasyon, bağımlılık/yetersizlik, hastalıklar ve zarar görme karşısında dayanıksızlık, yapışıklık, başarısızlık, boyun eğicilik, kendini feda, onay arayıcılık, karamsarlık, duygusal bastırma, yüksek standartlar, cezalandırıcılık).

Klinik psikoloji alanında terapötik ilişkinin tedavi sürecindeki önemine dikkat çekilmesine rağmen, literatürde ilişki döngüsünü neyin etkilediği üzerine kısıtlı sayıda araştırma vardır. Bundan dolayı, bu çalışmada şu amaçlara ulaşmak hedeflenmektedir: Young şema alanlarının, baş etme biçimlerinin ve ebeveyn biçimlerinin süpervizörler, terapistler ve hastalar arasındaki terapötik ilişkiye etki edip etmediğine bakmak; süpervizörlerin, terapistlerin ve hastaların terapötik ilişki tanımlarını karşılaştırmak; terapötik ittifakı ölçmek için örtük bir ölçüm aracı geliştirmek; Terapötik İttifak Ölçeği'nin süpervizör ve terapist formlarının Türkçe modifikasyonunun yapmak; terapötik ittifakın nitel ve nicel ölçümlerini kısıtlılıkları ve farklılıkları açısından kıyaslamaktır. 52 farklı ilişki biçiminin değerlendirildiği doktora tezinin bir parçası olan bu çalışmada, sadece bir vaka üzerinden değerlendirme yapılacaktır.

\section{Metod ve Yöntem}

$\mathrm{Bu}$ araştırmada hedeflere ulaşabilmek için metod olarak şöyle bir yöntem ve prosedür uygulanmıştır: Araştırma katılımcılar üç gruptan oluşmuştur. Birinci olarak, Orta Doğu Teknik Üniversitesi Klinik Psikoloji Doktora Programında öğrenim gören bir süpervizörden (Süpervizör A) oluşmuştur. Bu süpervizör, kıdemli öğretim görevlileri tarafından verilen süpervizyon altında en az iki yüz seans hasta görerek ve süpervizyon dersi alarak süpervizyon vermeye hak kazanmış doktora öğrencilerinden oluşan grup içerisinden seçilmiştir. Bu gruptaki süpervizörler kendi eğitim süreçlerinde ilk kez süpervizyon vermiştir. Bu nedenle, onların süpervizyon süreci de bölümdeki öğretim görevlileri tarafından ayda bir kez denetlenmiştir. Ayrıca, süpervizörler ayda bir kez de akran süpervizyonuna katılmışlardır. İkinci olarak çalışmaya katılan terapist, Orta Doğu Teknik Üniversitesi klinik psikoloji yüksek lisans programına devam eden terapistler içinden seçilen Terapist B olmuştur. TerapistB lisans programının ikinci yılına devam etmektedir ve bu programın ilk yılında psikoterapi dersi almıştır. Ayrıca, Terapist B de ilk kez psikoterapi sürecinde yer almıştır. Terapist B de diğer terapistlerle birlikte haftada bir kez süpervizyon almış ve ayda bir kez de lisansüstü öğrencileri ve klinik psikoloji programının öğretim üyelerine kendi vakasını 
sunmuştur. Süpervizör A ve Terapist B de diğer tüm süpervizör ve terapistler gibi vaka sunumları aracılığıyla da öğretim görevlileri tarafından değerlendirilmiştir. Tüm bu süpervizyon ve psikoterapi süreçleri Ayna Klinik Psikoloji Birimi tarafından sağlanmıştır. "Ayna", Orta Doğu Teknik Üniversitesi Psikoloji Bölümü'nde klinik psikoloji programına devam eden öğrencilerin stajı için tesis edilmiş bir klinik destek ünitesidir. Bu ünitede, yüksek lisans veya doktora eğitimine devam eden öğrenciler süpervizyon altında psikoterapi hizmeti vermektedir. Üçüncü olaraksa, depresyon, anksiyete, yakın ilişki sorunları şikayetleri ile Ayna'ya başvurmuş hastalardan çalışmaya gönüllü katılmak isteyen ve Terapist B'nin Süpervizör A gözetiminde takip ettiği bir hasta seçilmiştir. Ayna'ya başvuran hastalar çoğunlukla Orta Doğu Teknik Üniversitesi'nin farklı bölümlerinde öğrenim gören öğrenciler olmuştur. Araştırmada bahsi geçen Hasta $\mathrm{C}$ ise bağımlı kişilik örüntüsü ve ilişki problemleri nedeniyle üniteye başvurmuştur.

Bu çalışmada, iki tip ölçüm yöntemi kullanılmıştır. Birincisi, nicel ölçme yöntemidir. Nicel ölçüm için Demografik Bilgi Formu, Young Şema Ölçeği, Young Ebeveynlik Ölçeği, Young-Rygh Kaçınma Envanteri, Young Telafi Envanteri ile Terapötik İttifak Ölçekleri’nin süpervizör-terapist ve terapist-hasta formları kullanılmıştır (Detaylı bilgi için tezin orijinaline bakınız). İkinci olarak nitel ölçüm yöntemi kullanılmıştır. İlk olarak, süpervizörlerin ve terapistlerin süpervizyon sürecinde yaşadığı zorlukları ve bunlarla nasıl baş ettiklerini belirlemek için araştırmacı tarafından geliştirilen Açık Uçlu Soru Formu uygulanmıştır. Buna ek olarak, tüm katılımcıların örtük olarak süpervizyon ve psikoterapi süreçlerini nasıl algıladıklarını belirleyebilmek için İlişkisel Halkalar adında bir projektif ölçek geliştirilmiştir. Mevcut çalışma başlamadan önce, Ayna Klinik Psikoloji Birimi Direktörü ve Orta Doğu Teknik Üniversitesi Etik Komitesi'nden izin alınmıştır. Ayrıca, çalışmanın başında, katılımcıların bu çalışmaya gönüllü katılımını ifade ettikleri bilgilendirilmiş onam formu imzalatılmıştır. Gizliliği sağlamak için, öncelikle, katılımcılara araştırmaya dahil olmayan bir kişi tarafından takma isim verilmiştir. Araştırmacı takma isimlerin hangi kişiye ait olduğunu bilmemektedir. Ancak katılımcılara birbirleri için değerlendirme yapacaklarından takma isimlerin kime ait olduğu bilgisi verilmiştir. Süpervizörler "Süper" takma adı ile kodlanmış ve bu takma adın arkasına bir sayı (örneğin, SUPER1) atanmıştır. Ayrıca, terapistler "Freud" takma adı ile kodlanmış ve bir sayı bu takma adın arkasına (örneğin, Freud1) atanmıştır. Benzer şekilde, hastalar da "Kaşif” takma adıyla kodlanmış, bu kodun önüne bir sayı sonuna bir sayı eklenmiş; önüne eklenen sayı hastanın süpervizörünü, arkasına eklenen sayıysa terapistini temsil etmiştir (örneğin, 1Kaşif5). Ancak araştırmacı bu kodları tezde yazarken gizliliği sağlayabilmek için tekrar değiştirmiştir. Mevcut çalışmada üç grup ölçek verilmiştir. Birinci grup araştırmanın başında bir defaya mahsus olarak evde doldurulacak biçimde uygulanmıştır. Bu grubu Young Şema Ölçeği, Young Ebeveynlik Ölçeği, Young-Rygh Kaçınma Envanteri ve Young Telafi Envanteri oluşturmuştur. Terapötik ittifakı ölçen ikinci grupsa, literatüre göre ilişkinin en erken üç seanstan sonra başladığı düşünüldüğünden, terapi seansı veya süpervizyon seansı en az üç seans geçtikten sonra verilmiştir. Bu ölçekler her seans veya süpervizyon oturumu bitiminde katılımcılara uygulanmıştır. Bu amaçla, süpervizyon ve terapi odalarına, bir kutu ve zarf yerleştirilmiştir. Ayrıca hatırlatma notları da bu odaların içine yerleştirilmiştir. Her oturumun sonunda, katılımcıların ölçekleri doldurmaları, zarfın içine koymaları, zarfı kapatmaları ve zarfı kutuya atmaları beklenmiştir. Üçüncü grup olarak, her süpervizyon ve terapi sürecinin sonunda doldurulmak üzere, katılımcılara yapılandırılmamış ölçekler (örn. ilişkisel halkalar ve açık uçlu soru formu) verilmiştir. Katılımcılardan ilişkisel halkaları hedef, görev ve duygusal bağ açısından doldurmaları beklenmiştir. Hedef, görev ve duygusal bağ tanımlarına yönelik talimatlar ilişkisel halkaları doldurma işlemi başlamadan önce araştırmacı tarafından katılımcılara anlatılmıştır. Bordin'in (1979) kavramsallaştırılmasına dayanarak, amaçlar katılımcıların yaşadıkları durumlar çerçevesinde terapiden ve süpervizyondan kazanmayı umut ettikleri şeyler/beceriler olarak tanımlanmıştır. Görevler süpervizör ve terapist ya 
da terapist ve hastanın birlikte ulaşmak istedikleri amaçlar doğrultusunda hemfikir oldukları görev ve sorumlulukları içermiştir. Duygusal bağ ise süpervizör-terapist veya terapist-hasta arasındaki amaçlara ulaşmaya çabalarken oluşan yakınlık ve güven duygusu olarak tarif edilmiştir.

Bu çalışmada, nicel ölçüm yöntemlerinde diskriptif ve korelasyon amaçlı sonuçlara ulaşmak için SPSS kullanılmıştır. Nitel ölçümler ise nicel ölçümlerden çıkan sonuçlarla ilişkilendirilerek açıklanmaya çalışılmıştır.

Ölçeklerin deskriptif özelliklerini analiz edebilmek için, Young Şema Ölçeği (örn. terk edilme, güvensizlik/istismar edilme, duygusal yoksunluk, kusurluluk/utanç, sosyal izolasyon, bağımlılık/yetersizlik, hastalıklar ve zarar görme karşısında dayanıksızlık, yapışıklık, başarısızlık, boyun eğicilik, kendini feda, onay arayıcılık, karamsarlık, duygusal bastırma, yüksek standartlar, cezalandırıcılık); Young Ebeveynlik Ölçeği (kuralcı/kalıplayıc1, küçümseyici/kusur bulucu, duygusal bakımdan yoksun bırakıcı, sömürücü/istismar edici, aşırı koruyucu/evhamlı, koşullu/başarı odaklı, aşırı izin verici/sınırsız, kötümser/endişeli, cezalandırıcı, değişime kapalı/duygularını bastıran); Young-Rygh Kaçınma Ölçeği (örn. psikosomatizm, sıkıntıyı yok saymak, duygu kontrolü, sosyal çekilme, aktiviteyle zihinden uzaklaştırma, hissizlik, duyguları bastırma); Young Telafi Ölçeği’nin (örn. statü düşkünlüğü, kontrol, asilik, aşırı bağımsızlık, manipülatif olma, eleştiriye tahammülsüzlük, kendi yönelimlilik, mesafelilik) ortalamaları, standart sapmaları ve minimum-maksimum aralıkları değerlendirilmiştir. Bu analiz süpervizörler, terapistler ve hastalar için ayrı ayrı tekrarlanmıştır.

\section{Sonuçlar ve Tartışma: Süpervizör A- Terapist B- Hasta C'nin Vaka Analizi}

Çalışmada süpervizör, terapist ve hasta arasındaki ilişkiyi değerlendirebilmek için öncelikle herbirine Young Şema Ölçeği, Young Rygh Kaçınma Ölçeği, Young Telafi Ölçeği ve Young Anne-Baba Ölçeği ile Terapötik İttifak Ölçekleri uygulanmıştır. Şema ölçekleri sadece çalışmanın başında bir defaya mahsus bilgi toplama amacı ile uygulanmış; ittifak ölçekleri ise her süpervizyon ve terapi seansı sonrası olmak üzere uygulatılmıştır.

Bu vaka örneğinde Süpervizör A, bilişsel davranışçı terapi, bağlanma kuramı ve dinamik yaklaşımdan oluşan eklektik bir süpervizyon süreci izlemektedir. Diğer taraftan, Terapist B ise bağımlı kişilik bozukluğuna sahip ve ilişki kurmakta problem yaşayan Hasta $\mathrm{C}$ ile terapisinde BDT ile ilişki odaklı bir terapi yaklaşımı benimsemektedir.

\section{Süpervizör A Kimdir?}

Araştırmada çıkan sonuçlara göre, Süpervizör A'da terk edilme, onay arayıcılık, yetersiz özdenetim, kusurluluk ve kendini feda şemaları olduğu dikkati çekmiştir. Bu şemaları telafi etmek içinse kontrol, statü düşkünlüğü, mesafelilik ve aşırı bağımsızlığın Süpervizör A tarafından sıklıkla kullanıldığı bilgisi elde edilmiştir. Diğer taraftan sosyal çekilme, duygu kontrolü ve psikosomatizm ise kaçınma baş etme yöntemi olarak kullanılan stratejilerdir. Bunların yanı sıra, Süpervizör A’nın kötümser/endişeli, duygusal bakımdan yoksun bırakıcı, aşırı izin verici/sınırsız, koşullu/başarı odaklı özelliklerinde anneye ve kötümser/endişeli, duygusal bakımdan yoksun bırakıcı, aşırı izin verici/sınırsız, koşullu/başarı odaklı özelliklerinde babaya sahip olduğu bulunmuştur.

\section{Terapist B Kimdir?}

Terapist B'ye gelince, dikati çeken şemaların kendini feda, yüksek standartlar, onay arayıcılık, haklılık/büyüklenmecilik ve yetersiz özdenetim olduğu belirlenmiştir. Terapist B 
tarafından şemalardan kaçınmak için en fazla kullanılan baş etme stratejileri ise mesafelilik, statü düşkünlügü, kontrol, eleştiriye tahammülsüzlük, aşırı bağımsızlık ve manipülasyondur.

Aktiviteyle zihinden uzaklaşmak, duygu kontrolü, sıkıntıyı yok saymak ve sosyal çekilme ise Terapist B'nin kullandığı telafi yöntemleridir. Ebeveynlik değerlendirmelerine göre, Terapist B, duygusal bakımdan yoksun bırakıcı, koşullu/başarı odaklı, cezalandırıcı, aşırı koruyucu/evhamlı, değişime kapalı/duygularını bastıran ve kuralcı/kalıplayıcı anne özellikleri ile kuralcı/kalıplayıcı, koşullu/başarı odaklı, değişime kapalı/duygularını bastıran, küçümseyici/kusur bulucu, and aşırı izin verici/sınırsız baba özellikleri rapor etmiştir.

\section{Hasta C Kimdir?}

Hasta C'nin değerlendirmelerine göre, en çok dikkati çeken şemalarının haklılık/büyüklenmecilik, kendini feda, yüksek standartlar, terk edilme, karamsarlık, cezalandırıcılık ve yetersiz özdenetim olduğu saptanmıştır. Bütün telafi yöntemlerinin (örn., mesafelilik, eleştiriye tahammülsüzlük, kontrol, aşıı bağımsızlık, kendi yönelimlilik, statü düşkünlüğü, asilik ve manipülasyon) Hasta C tarafından sıklıkla kullanılırken, mesafeliliğin aşırı derecede kullanıldığı dikkati çekmiştir. Ayrıca, aktiviteyle zihinden uzaklaştırma, sosyal çekilme, duygusal kontrol, sıkıntıyı yok saymak ve Psikosomatizm Hasta C'nin sık kullandığı kaçınma yöntemleridir. Diğer bir taraftan, duygusal bakımdan yoksun bırakıcı, aşırı koruyucu/evhamlı, kuralcı/kalıplayıcı ve koşullu/başarı odaklı anne özellikleri ile değişime kapalı/duygularını bastıran ve küçümseyici/kusur bulucu baba özellikleri Hasta C'nin ebeveyn özelliklerini göstermektedir.

\section{Süpervizör A ve Terapist B Arasındaki Terapötik İttifakın Şema Teorisi ile İlişkisi}

Süpervizör A ve Terapist B arasındaki terapötik ittifakı değerlendirmek için, yedi defa ölçüm alınmıştır. Bu ölçümlerden, genel, amaç, görev ve duygusal bağ odaklı terapötik ittifaka dayalı ortalamalar elde edilmiştir. Elde edilen ortalamalardan Süpervizör A ve Terapist B arasında kıyaslamalar yapılmış ve bu kıyaslamalar Erken Yaş Dönemi Uyumsuz Şemalar, Young Ebeveynlik Ölçeği ölçümleri, Young-Rygh Kaçınma Ölçeği alt ölçekleri, Young Telafi Ölçeği ölçümleri ile ilişkilendirilmiştir.

\section{Süpervizör A ve Terapist B arasındaki Niceliksel Ölçümlere Dayalı Terapötik İttifak ve Bunun Şema Teorisi ile İlişkisi}

Süpervizör A ve Terapist B arasındaki genel terapötik ittifak sonuçlarına göre, Süpervizör A'nın Terapist B'ye göre daha fazla terapötik ittifak algıladığı belirlenmiştir (Figür 1). Ölçümlerin başlangıcında, Süpervizör A, Terapist B ile ilişkisinde en yüksek ittifak skorunu belirtmiştir (Figür 1). Daha sonra, zaman ilerledikçe bu skorlarda bir dalgalanma olduğu dikkati çekmektedir. Süpervizör A'nın en yüksek skoru verdiği zaman Terapist B'nin en düşük skoru verdiği seansa denk gelmiştir. Diğer taraftan, Terapist B en düşük skoru değerlendirmelerin başında vermiştir. Sonra Terapist B'nin süpervizyon süreci için değerlendirmeleri dereceli olarak artmıştır. Ancak Süpervizör A'nın Terapist B ile ilişkisinde en düşük skoru verdiği süpervizyon seansında ( 9 . seans), ilginç bir şekilde Terapist B Süpervizör A için en yüksek skoru vermiştir. Bu sonuca göre, Süpervizör A ve Terapist B arasında ele alınmayan veya konuşulmayan konular olduğu düşünülmüştür. Ayrıca Süpervizör A tarafından iyi veya kötü olarak algılanan durumların Terapist $\mathrm{B}$ için karşıt anlama geldiği dikkati çekmektedir. İlişki kurma biçimleri arasında bir fark olduğu düşünülmüştür. 


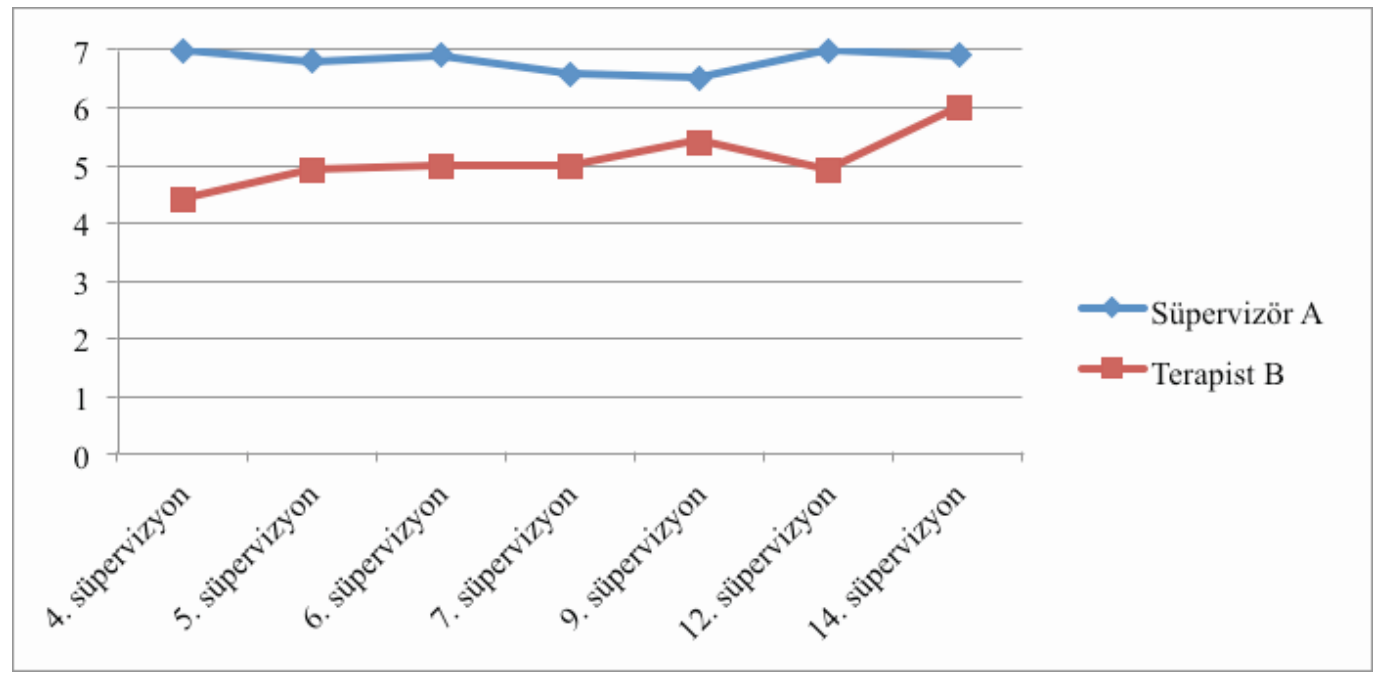

Figür 1. Süpervizör A ve Terapist B arasındaki genel terapötik ittifak

Ayrıca, amaç, görev ve duygusal bağ odaklı terapötik ittifak değerlendirmelerinde (Figür 2, Figür 3, Figür 4), Süpervizör A'nın değerlendirmelerinde belirgin bir düşüş (7. süpervizyon seansı) olduğu dikkati çekmiştir. Bununla birlikte, Terapist B'nin bu durumun farkında olmadığ 1 anlaşılmaktadır. Belki de Süpervizör A bu durumu göz ardı etmiş veya süpervizyon sürecinde ele almamıştır. Benzer olarak, 12. süpervizyon oturumunda, Terapist B'nin verdiği duygu odaklı terapötik ittifak değerlendirmesinde belirgin bir düşüş olmuştur (Figür 4) ve bu durum Süpervizör A tarafından fark edilmemiştir. Buradan Süpervizör A ve Terapist B arasında süpervizyon sürecinde açık ve net iletişim kurma eksikliği olduğu düşünülmüştür.

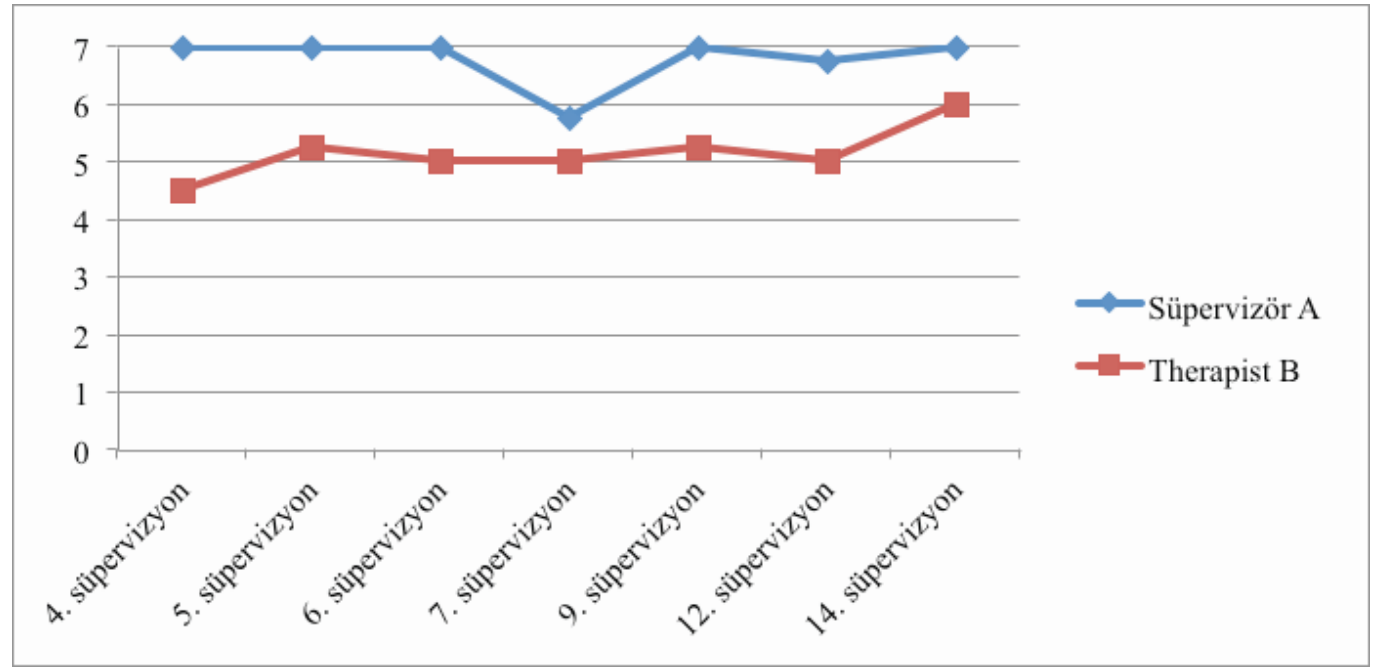

Figür 2. Süpervizör A ve Terapist B arasındaki amaç odaklı terapötik ittifak 


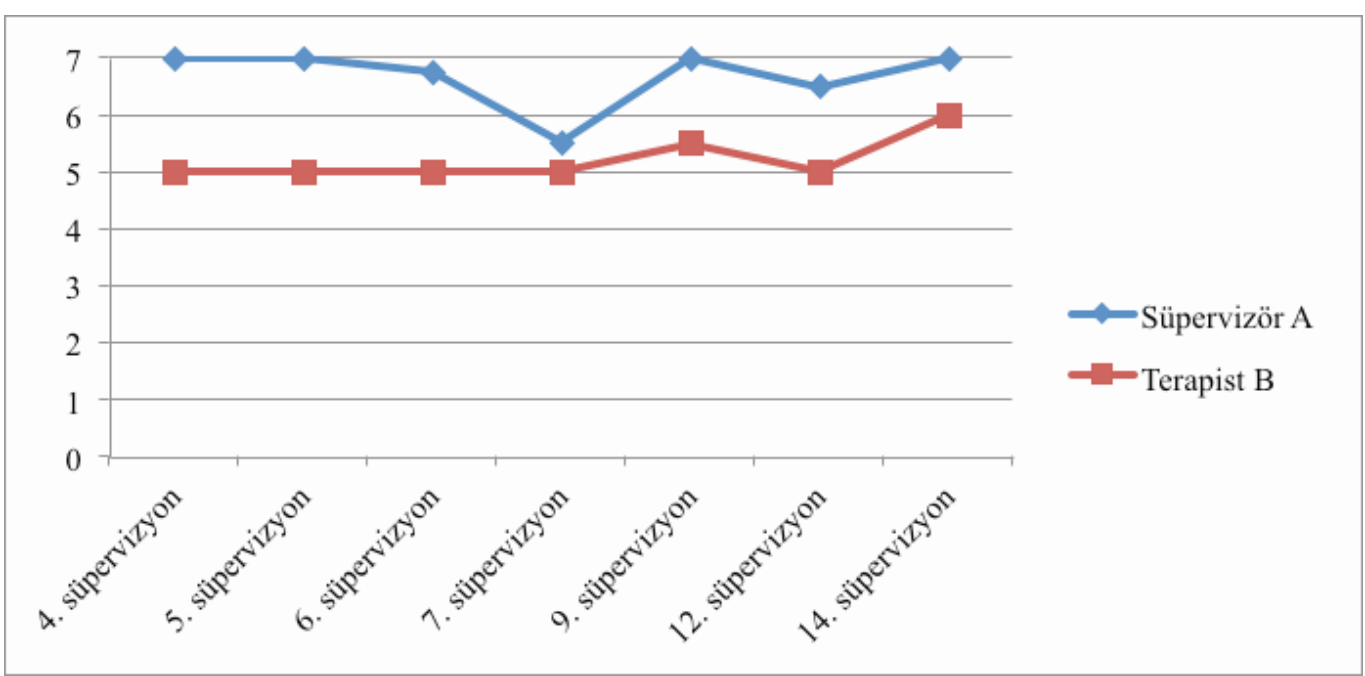

Figür 3. Süpervizör A ve Terapist B arasındaki görev odaklı terapötik ittifak

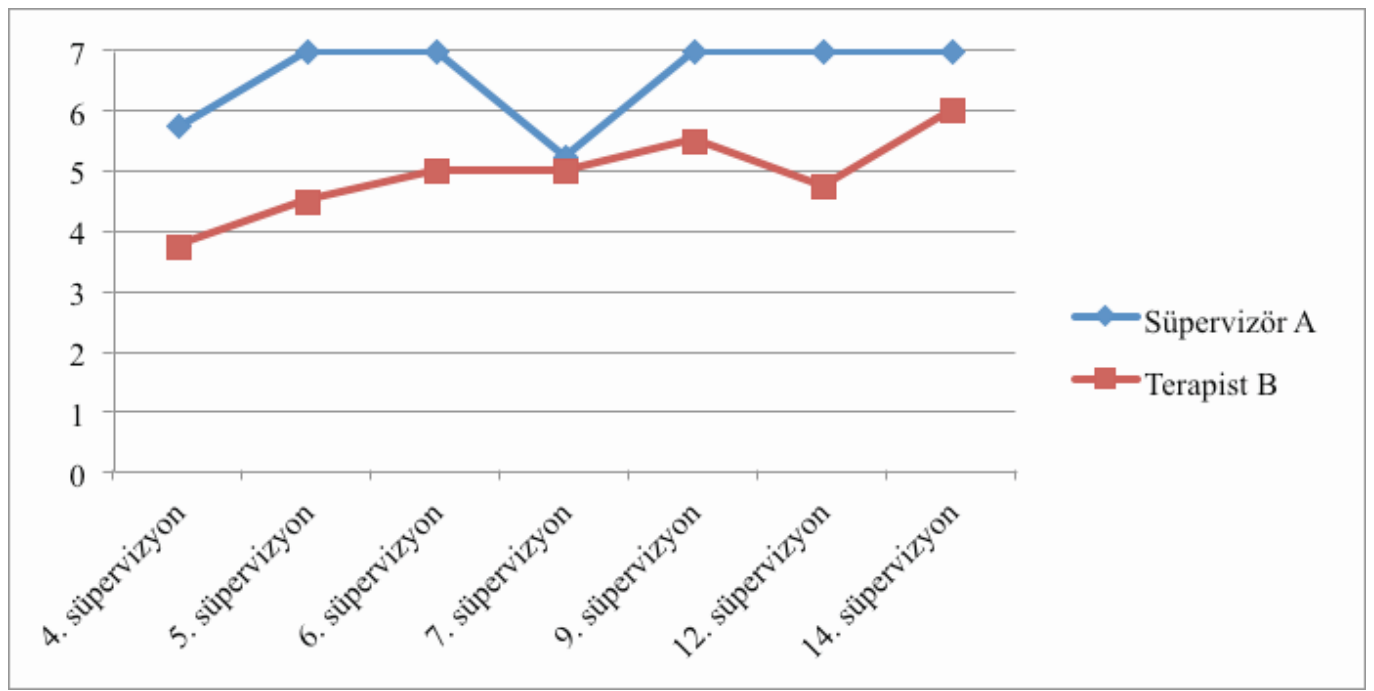

Figür 4. Süpervizör A ve Terapist B arasındaki Duygu Odaklı Terapötik İttifak

Tüm bu sonuçlardan yola çıkarak, ilk olarak, Terapist B'nin ittifak ile ilgili düşük skorlar verme eğilimi onun yüksek standartlar ve haklılık şemaları ile açıklanabilir. Young'ın (1999) belirttiği gibi, bu şemalara sahip olan kişiler başkalarını veya başarıları değerlendirirken küçümsemek veya değersizleştirmek eğiliminde olabiliyorlar. Ayrıca, Süpervizör A'nın daha yüksek skorla değerlendirmelere başlamış olması onun kötümser ve başarı odaklı ebeveynleri ile mücadelesinden kaynaklanıyor olabilir. Belki Süpervizör A kendi ebeveynlerinin ona yaptığı gibi bir rolde olmayı seçmek istememiştir. Klein'a göre (1952), sağlıksız tutumları olan ebeveynler kendi karşılanmamış ihtiyaç ve isteklerini çocuklarına yüklemek için yansıtmalı özdeşimi kullanmaktadır. Buna ek olarak, Cashdan (1988) yansıtmalı özdeşimin bir kişiyi kendi istek ve beklentilerine göre davranmaya zorlamak olduğunu iddia etmiştir. Ancak, eğer bu duruma zorlanılan kişi bu davranışlara zorlayan kişiden farklı kişilik özelliklerine sahipse veya zorlanılan kişi terapötik bir farkındalığa sahipse, Süpervizör A'nın yaptığı gibi, bu sağlıksız döngü içine 
girmeyi reddedebilir. Çünkü geçmişte duygularını açıkça ifade edememiş ve bastırmış olma ihtimali, duyguların değerlendirmede etkili olmasına neden olmuş olabilir (düşüş) (Gross, 2002). Ek olarak, Terapist B ve Süpervizör A tarafından kullanılan duygusal kontrol sağlıksız baş etme şekli, süpervizyonda açık ve net iletişim eksikliğine sebep olmuş olabilir.

\section{Süpervizör A ve Terapist B arasındaki Nitel Ölçümlere Dayalı Terapötik İttifak ve Bunun Şema Teorisi ile İlişskisi}

Süpervizör A’nın ilişkisel halkalara dayalı ölçümlerine bakıldığında (bkz. Figür 5), Süpervizör A süpervizörün ve terapistin paylaştıkları amaçları olduğunu düşünmüştür; ancak, hasta Süpervizör A’nın algısına göre ortak paylaşılan amaçlar içerisinde yer almamıştır. Terapist B süpervizör, terapist ve hasta arasında dengeli paylaşılmış veya bağımsız olan amaçlar olduğunu düşünmüştür (bkz. Figür 5). Sonuçlara bakıldığında, Süpervizör A ve Terapist B arasında amaç odaklı terapötik ittifak için paralel olmayan bir algı saptanmıştır. Süpervizör A açısında, amaçları değerlendirirken Süpervizör A’nın yalnızca süpervizör ve terapist odaklı düşündügü dikkati çekmiş; hasta ile paylaşılan amaçlar göz ardı edilmiştir. Bu durum süpervizörün ilk kez süpervizörlük yapmasından ve terapist ve hasta arasındaki ortak amaçları dengeli dağıtamamış olmasından kaynaklanıyor olabilir. Buna ek olarak, Süpervizör A'nın şemaları ve şemalarının kökenlerine bakıldığında, Süpervizör A duygusal bakımdan yoksun bırakıcı ve koşullu/başarı odaklı ebeveyn kökenine bağlı olarak, Terapist B tarafindan terk edilmekten ve onay alamamaktan korkmuş olabilir. Ladany, Constantine, Miller ve Erickson'a göre (2000), süpervizörlerin halledilmemiş geçmiş meseleleri süpervizyon ortamını etkileyebilir. Sağlıksız çocukluk deneyimlerinin etkisi ile baş etmek için, Süpervizör A, sağlısıı baş etme biçimi olarak kontrol etmeye çalışırken terapiste fazla odaklanarak hastanın amaçlarını göz ardı etmiş olabilir. Bunun tersine, Ladany, Constantine, Miller ve Erickson (2000) süpervizörlerin terapistle yaşadığı zorluklarda kontrolü artırmak yerine süpervizyonda dile getirmesinin ilişkiyi sağlamlaştırdığını vurgulamışlardır. Diğer bir taraftan, Terapist B'nin süpervizyon sürecini daha gerçekçi değerlendirdiği söylenebilir.

Görev açısından (bkz. Figür 5), Süpervizör A, süpervizör, terapist ve hasta arasında paylaşılan ve bağımsız görevleri dengeli dağılmış bir şekilde algıladığını belirtmiştir. Diğer bir taraftan, Terapist B, terapist ve hasta arasındaki görev paylaşımında eşit büyüklükte, çakışık ve süpervizöre göre daha büyük bir görev paylaşımı bildirmiştir; ancak süpervizör için en küçük ve tamamen terapist ve hastanın görevlerine bağımlı bir görev paylaşımı algıladığını göstermiştir. Çıkan bu sonuca göre, Süpervizör A'nın bu süreçteki herkesin eşit sorumluluklara sahip olduğunu düşündüğü çıkarılabilir. Diğer taraftan, Terapist B, Süpervizör A'nın Terapist B ve Hasta C'den bağımsız bir sorumluluğunun olmadığını düşünmektedir. Buna ek olarak, Süpervizör A bu grupta en az sorumluluğa sahip kişi olarak algılanmıştır. Buradan hareketle, Terapist B'nin Süpervizör A’nın katkısını hafife aldığı anlaşılmaktadır. Bu durum Terapist B'nin gizli öfkesinden kaynaklanıyor olabilir (bastırılmış duygu, Gross, 2002). Belki de Terapist B yüksek standartlar, kusurluluk ve haklılık/büyüklenmecilik şemalarına sahip olduğu için, kendinden yüksek beklentilerle sorumluluklarını abartmış ve yeterli olduğu inancını devam ettirerek, kendi anne babasının duygusal bakımdan yoksun bırakıcı, koşullu/başarı odaklı ile küçümseyici/kusur bulucu özelliklerini süpervizörüne aktarmıştır (Young'ın çocukluktaki çözümlenmemiş meselelerin etkisinde dile getirdiği gibi, 1999). Diğer taraftan, bu durum hastanın yansıtmalı özdeşiminden kaynaklanmış olabilir. Klein'ın belirttiği gibi (1952) hastanın yansıtmalı özdeşimi doğrultusunda, Terapist B kendini hastası ile bağımlı bir örüntüde konumlamış ve süpervizörün farkında olmamış olabilir (hastanın anne ile birleşme arzusunun aktarımına bir cevap olarak/hastanın döngüsüne girmek). Bunun yanı sıra, Terapist B Hasta C ile eşit bir sorumluluk algısı tanımlamıştır. Bu da 
terapistin kendini feda veya haklılık/büyüklenmecilik şemalarından kaynaklı olabilir. İlk olarak, terapist başkaları yönelimlilik şema alanından gelen şemalara sahip olduğu için, hastanın sorumluluk paylaşımına fazla değer vermiş olabilir (Young, Klosko ve Weishaar, 2003). İkinci olarak, hem terapist hem de hasta haklılık/büyüklenmecilik şeması ile eleştiriye tahammülsüzlük telafi biçimine sahiptir. Bu yüzden, Terapist B bu şemasını telafi ederek hastasının fazla sorumluluk aldığını yansıtmaya ihtiyaç duymuş olabilir (Young, 1996).

Duygusal bağ odaklı terapötik ittifaka gelince (bkz. Figür 5), Süpervizör A terapist ve hasta için iç içe geçmiş bir ittifak ve kendisi için de bu iç içe geçmiş ittifakta küçük bir pay tasvir etmiştir. Ancak, Terapist B süpervizör, terapist ve hasta arasında sağlıklı olmayan bir ittifak tanımlamıştır. Terapist ve süpervizör bu konuda benzer bir bakış açısına sahiptir. Buradan anlaşıldığı gibi, terapist ve hasta arasındaki iç içe geçmiş bağın hem süpervizör hem de terapist farkındadır ve bunu sağlıklı görmemektedirler. Ancak, Süpervizör A kendi için bu bağda küçük bir kesişim tanımlarken, Terapist B onu da tamamen iç içe geçmiş olarak tasvir etmiştir. Bu bakış açılarından yola çıkarak, hastanın bağımlı kişilik örüntüsünün yansıtmalı özdeşimle terapötik ilişkiye yayıldığı çıkarılabilir (yansıtmalı özdeşim/başkalarını kişinin kendi psikolojik ihtiyaçları doğrultusunda davranmaya zorlaması, Cashdan'1n 1988'de belirttiği gibi). Belki de, Süpervizör A terapist ve hastanın arasındaki güçlü bağımlı yapının farkındadır ancak müdahale etmek istememiştir. Belki de bu süpervizörün terk edilme şemasına bağlı olarak kendisini yalnız hissetmesine sebep olmuştur. Belki de bu durumla baş edemeyen süpervizör sosyal çekilme ile baş etmeye çalışmaktadır. Diğer bir taraftan, Terapist B'nin iç içe geçmiş sağlıksız yapısının farkında olmasına rağmen, yüksek standartlar, kendini feda ve aşırı kabul ve onay ihtiyacı doğrultusunda davranmaya devam etmiş olabilir (terapistin kendi şemalarının etkisi/ Young, Klosko ve Weishaar, 2003). Buna bağlı olarak terapist statü düşkünlüğü ile bu bağımlı ilişkide karşılanmamış çocukluk ihtiyaçlarını karşılama firsatı bulduğu için iyi hissetmiştir. Ancak, iç içe geçmiş ilişki iyileştirici değildir, çünkü bu ilişki biçimi gelişmemiş benlik, terk edilme ve yetersiz özdenetim şemalarının da güçlenerek yaşamasına sebep olmaktadır (hastanın şemalarından birinin terapistin şemaları ile çakışması/ Young, Klosko ve Weishaar, 2003).

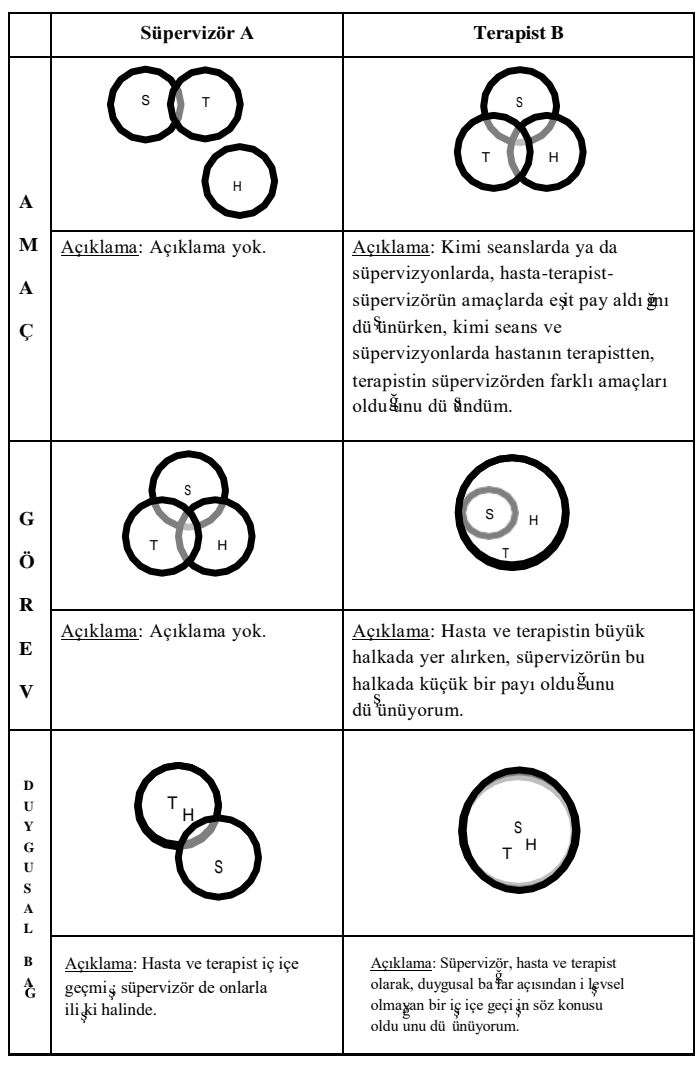

Figür 5. Süpervizör A ve Terapist B için terapötik ittifakın projektif ölçümleri

Not: $\mathrm{S}=$ Süpervizör $\mathrm{A}, \mathrm{T}=$ Terapist $\mathrm{B}, \mathrm{H}=$ Hasta 
Açık uçlu soruların cevaplarına göre (Figür 6 ve Figür 7), Süpervizör A terapistlerden birine kızgın olduğunu, önce bu kızgınlığını göstermediği ve daha sonra bunu süpervizyonda ele almaya çalıştığını ifade etmiştir. Bunun da olumlu ve olumsuz sonuçları olmuştur. Diğer bir taraftan, Terapist B (Figür 3'te gösterildiği gibi) de süpervizörlerden birine kızgın olduğunu bildirmiştir. Terapist B karşılıklı bir öfkeden bahsetmektedir. Süpervizörün öfkeyi ele alış biçimi terapisti zorlamıştır. Hem süpervizör hem de terapist akademik grupla durumu paylaşmış ve destek almak istemişstir. Tüm bu cevaplar, hem Süpervizör A'nın hem de Terapist B'nin duygularını ifade etmekte, ele almakta ve öfke yönetiminde güçlük yaşadıklarını göstermektedir. İkisi de duygu kontrolünü sağlıksız baş etme biçimi olarak kullanmaya meyillidir. Ancak, duygularını ifade ederek bu kontrolü kırmaya çalışmışlardır. Öte yandan, bu ilk kez yapıldığı için yeterince işlevsel ve çözüm getirici olmamıştır terapist için. Bu noktada akran süpervizyonunun ve süpervizyon vermeye başlanıldığında bunun da süpervize edilmesinin önemi dikkati çekmektedir.

\section{Süpervizyon sürecinde yaşadığınız en büyük güçlük ne oldu? Terapistlerden birine öfkelendim. Öfkemi hiç yansıtmadım. Aslında çok etkilenmiştim. Bir sonraki hafta "ele alabileceğimi" düşünerek konuyu açtım. Fakat çok duygusal bir ortam oldu (olumlu ve olumsuz yönleri var) \\ Bununla nasıl başa çıktınız? \\ Akran ve süpervizyon süpervizyonları ile.}

Figür 6. Süpervizör A için açık uçlu sorular ve yanıtları

Süpervizyon sürecinde yaşadığınız en büyük güçlük ne oldu?
Süpervizörümle aramdaki duygusal süreç; öfke duygusunun karşılıklı
varlığı ve süpervizyondaki teması, bunun ele alınma şekli (süpervizör
tarafindan) ve sonraki süreçler, benim açımdan zorlandığım, en büyük
güçlük diyebileceğim zamanlardı, süreç içerisinde.
Bununla nasıl başa çıktınız?
Duygularımın farkında olarak, karşı tarafı anlamaya çalışarak,
zorlandığım zamanlarda bunu tek başıma aşmak yerine süreç içerisinde
yer alan başka kişilerle konuşarak, bireysel süpervizyon eşliğinde ele
almaya, başa çıkmaya çalıştım.

Figür 7. Terapist B için açık uçlu sorular ve yanıtları

\section{Terapist B ve Hasta C Arasındaki Terapötik İttifak ve Bunun Şema Teorisi ile İlişkisi}

Terapist B ve Hasta C arasındaki terapötik ittifakı ölçmek için, on dört defa ölçüm alınabilmiştir. Bu ölçümlerden genel, amaç, görev ve duygusal bağ odaklı terapötik ittifak ortalamalarına ulaşılmıştır. Elde edilen skorlar Terapist B ve Hasta C arasında kıyaslamalar yapılarak, bu kıyaslamalar Erken Yaş Dönemi Uyumsuz Şemalar [örn., duygusal yoksunluk, terk edilme, güvensizlik/suistimal edilme, sosyal izolasyon/yabancilaşma, kusurluluk/utanç, başarısızlık, bağımlılık/yetersizlik, tehditlere karşı dayanıksızlık, boyun eğicilik, kendini feda, duyguları bastırma, yüksek standartlar, haklılık/büyüklenmecilik, yetersiz özdenetim, onay arayıcılık, karamsarlık ve cezalandırıcılık], Young Ebeveynlik Ölçeği ölçümleri [örn., duygusal bakımdan yoksun bırakıcı, aşırı koruyucu/evhamlı, küçümseyici/kusur bulucu, kötümser/endişeli, kuralc1/kalıplayıcı, değişime kapalı/duygularını bastıran, cezalandırıcı, koşullu/başarı odaklı, aşırı izin verici/sınırsız ve sömürücü/istismar edici ebeveynlik], Young-Rygh Kaçınma Ölçeği alt ölçekleri [örn., psikosomatik semptomlar, üzüntüyü yok saymak, duygusal kontrol, sosyal 
çekilme, aktiviteyle zihinden uzaklaştırma ve hissizlik/duyguları bastırma], Young Telafi Ölçeği ölçümleri [örn., statü düşkünlüğü, kontrol, asilik, aşırı bağımsızlık, manipülasyon, eleştiriye tahammülsüzlük ve kendi yönelimlilik] ile ilişkilendirilmiştir.

\section{Terapist B ve Hasta C arasındaki Nicel Ölçümlere Dayalı Terapötik İttifak ve Bunun Şema Teorisi ile İlişkisi}

Terapist B ve Hasta C arasındaki genel terapötik ittifaka bakıldığında (Figür 8), Terapist B daha dalgalı ve düşük seviyede bir terapötik ittifak algıladığını bildirmiştir. Bu durum Terapist B'nin yüksek standartlar şemasından kaynaklanmaktadır. Ayrıca, bu şema süpervizyon sürecinde aktive olmuş olabilir çünkü Terapist B ilk defa terapi hizmeti vermeye başlamıştır ve performans kaygısı ile baş etmeye çalışmaktadır. Diğer bir taraftan, Terapist B haklılık/büyüklenmecilik şemasına sahip olduğu için, genç bir terapist olarak ve koşullu/başarı odaklı bir ebeveyn yapısına da sahip olduğu için, problemlerle baş etmeye çalışırken kendini olduğundan daha iyi değerlendirmiş olabilir (hastanın ve terapistin örtüşen veya çarpışan şemalarına bağlı olara, Young'ın terapide risk olarak tanımladığ 1 gibi, 1996). Ayrıca, Hasta C, tüm ittifak çeşitleri için Terapist B'ye göre daha dalgasız bir terapötik değerlendirmesine sahiptir (Figür 8, Figür 9, Figür 10 ve Figür 11'de gösterildiği gibi). Bu durum duygusal bakımdan yoksun bırakıcı anne ile büyüyen hastanın terapisti idealize etmesinden kaynaklanmış olabilir (anneyle bütünleşme arzusu/ Klein, 1952). Belki de hasta duygularının paylaşılmasına ve dinlenilmeye ihtiyaç duymuştur; terapist de bu ihtiyaçların tümünü karşılar bir pozisyonda olmuştur. Buna ek olarak, Terapist B'nin genel terapötik ittifak değerlendirmesinde düşüş olduğu noktada, Hasta C bir yükselme rapor etmiştir (13. ve 16. Seanslarda olduğu gibi). Bu durum sağlıssız baş etme biçimleri ile açıklanabilir (örn., duygusal kontrol, sıkıntıyı yok saymak ve sosyal çekilme). Baş etme biçimlerine bağlı olarak, eğer bir problem varsa, bu detaylı olarak ele alınmamış olabilir ve belki de bunun üzerine hiç konuşulmamış olabilir (hasta ve terapistin şemalarının binişmesi ve aşırı özdeşimden dolayı/Young, 1996). Buna ek olarak, Terapist B Hasta C ile duygusal bağ odaklı terapötik ittifak açısından yoğun bir benzerlik göstermiştir (Figür 11). Belki de, terapist hastasıyla terapi sürecinde ortak amaç ve hedefler olduğundan emin değildir ancak duygusal bağ odaklı bir ittifakın olduğundan emindir. Bu durum, Terapist B'nin amaç ve görev odaklı ittifakı yüksek standartlar ve haklılık/büyüklenmecilik şemaları ile duygusal bakımdan yoksun bırakıcı, koşullu/başarı odaklı, cezalandırıcı anne ve kuralcı/kalıplayıcı, koşullu/başarı odaklı, küçümseyici/kusur bulucu baba gözüyle değerlendirmesinden kaynaklanıyor olabillir. Bu yapıya rağmen duyguları ve yakınlığı değerlendirirken daha pozitif davranmış olabilir çünkü Terapist B duygusal bakımdan yoksun bırakıcı bir ebeveyn yapısına sahip olarak büyümüş; buna bağlı olarak da bunu telafi etmek için duygusal bağ kurmak konusunda daha duyarlı davranıyor olabilir. $\mathrm{Bu}$ sayede, terapist çocuklukta alamadığı duygusal paylaşımı yaşıyor olabilir (terapistin ve hastanın şemalarının çatışması/hastanın terapistin şemalarından kaynaklı ihtiyaçlarını karşılamasının tatmini, Young, Klosko ve Weishaar, 2003). 


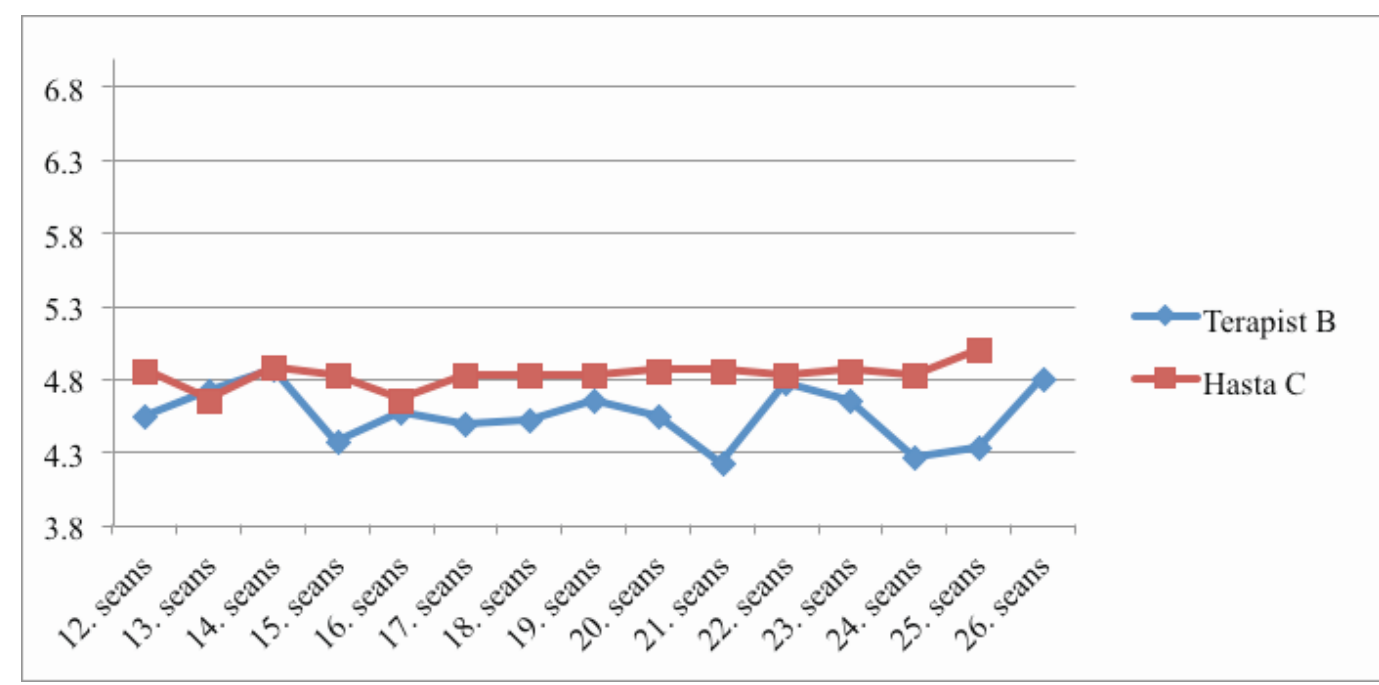

Figür 8. Terapist B ve Hasta C arasındaki genel terapötik ittifak

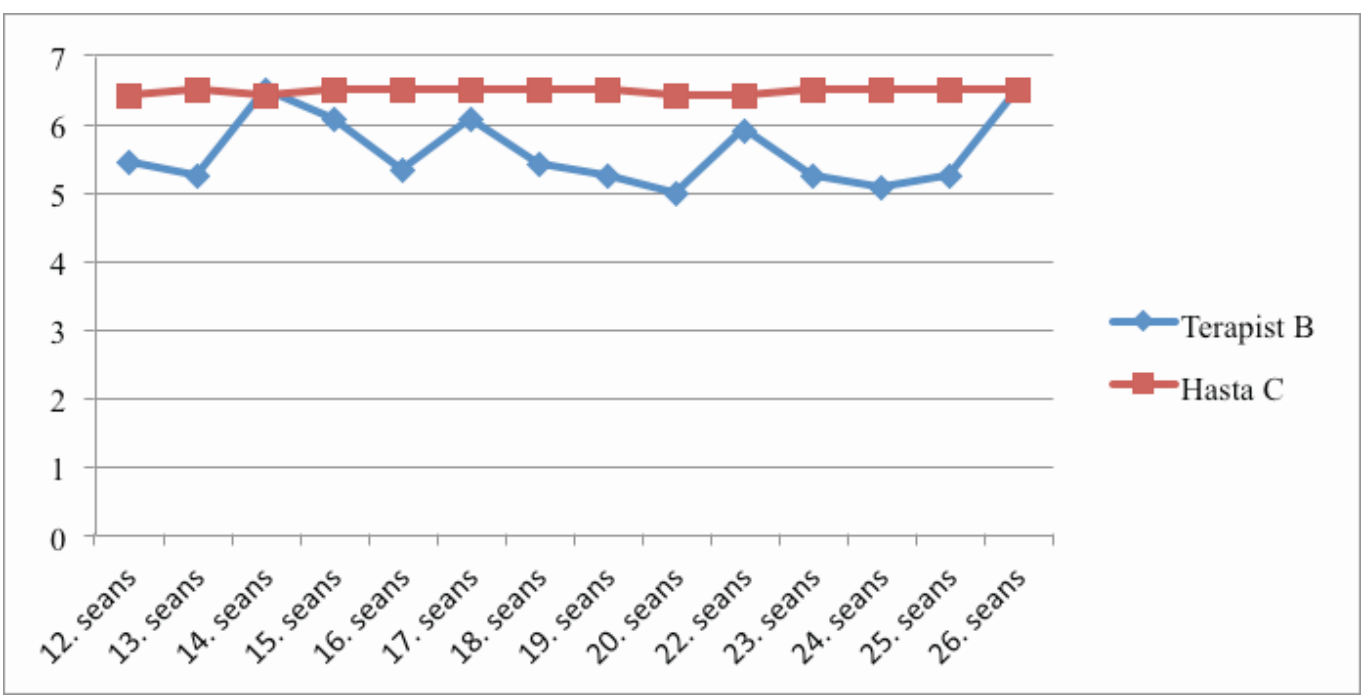

Figür 9. Terapist $\mathrm{B}$ ve Hasta $\mathrm{C}$ arasındaki amaç odaklı terapötik ittifak

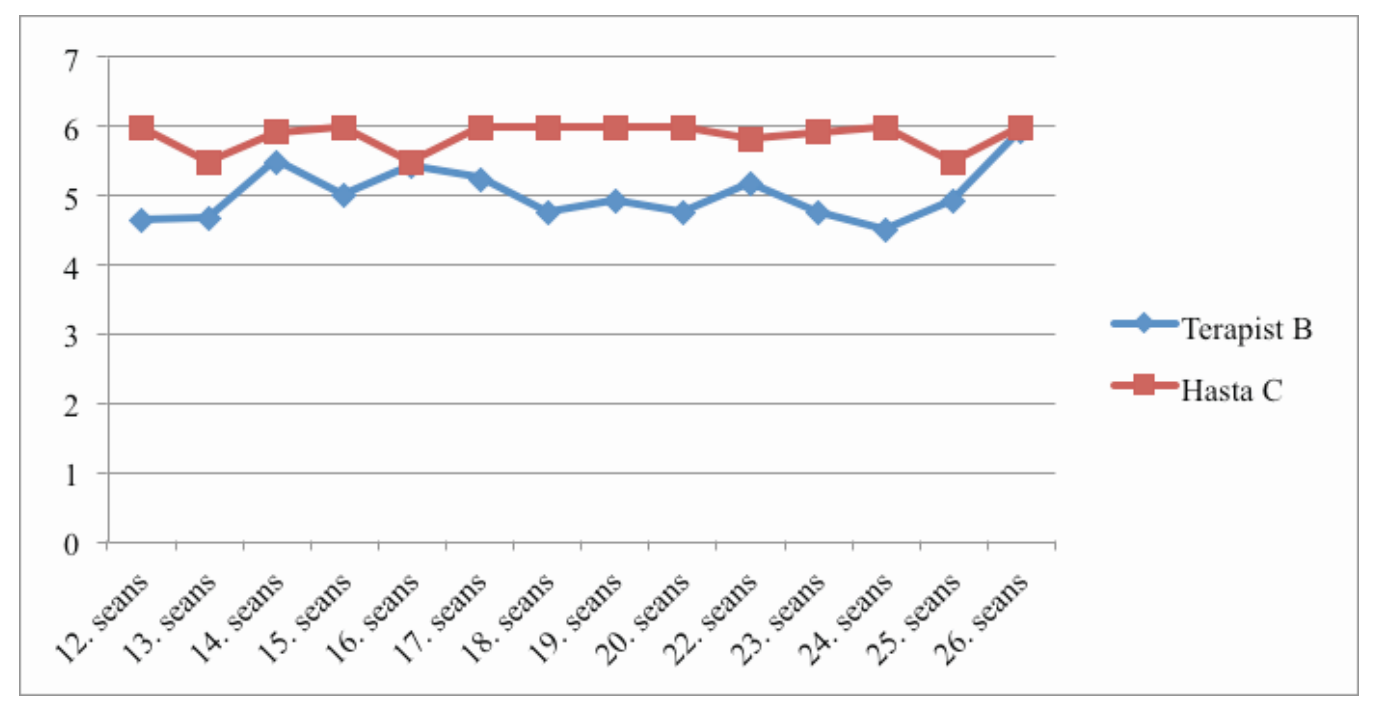

Figür 10. Terapist B ve Hasta C arasındaki görev odaklı terapötik ittifak 


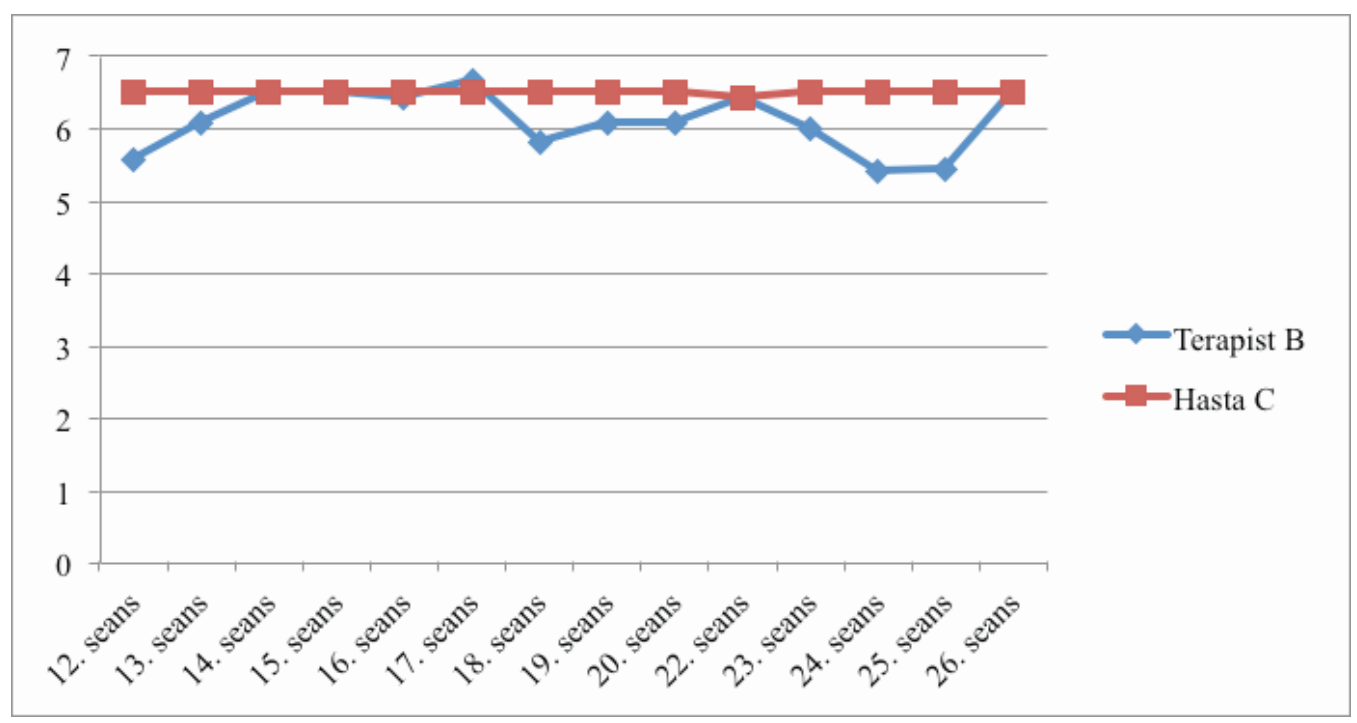

Figür 11. Terapist B ve Hasta C arasındaki duygusal bağ odaklı terapötik ittifak

\section{Terapist B ve Hasta C arasındaki Nitel Ölçümlere Dayalı Terapötik İttifak ve Bunun Şema Teorisi ile İlişkisi}

Projektif ölçümlere göre (Figür 6), Terapist B terapist, süpervizör ve hasta arasında eşit paylaşılmış ve bağımsız alanlar içeren amaç, görev ve duygusal bağ odaklı bir terapötik ittifak tanımlamıştır. Hasta $C$ ise bütün amaçların kendi üzerinden tanımlandığı bir ilişki belirtmiştir. Ayrıca, Hasta C'nin terapistin ve süpervizörün bütün amaçlarını, terapistin de süpervizörün tüm amaçlarını kapsadığı bir ilişki biçimi tasvir etmiştir. Bu durum Hasta C'nin ihmal edilmiş çocukluk çağı ihtiyaçlarının bir telafissi gibi değerlendirilebilir. Buradan hareketle Hasta $C$ her şeyin kendisi için ve kendisine bağımsız olmayan şekilde yapıldığını düşünmüş olabilir. Bir noktaya kadar, bu durum gerçekçi kabul edilebilir çünkü psikoterapi hastanın varlığ1 odaklı ve ihtiyacı yönünde devam etmektedir. Ancak, buradaki açıklamada hasta belki de kendi ilişki döngüsü içerisinde, duygusal bakımdan yoksun bırakıcı, küçümseyici/kusur bulucu, koşullu/başarı odaklı bir ebeveyn kökeninde büyümüş biri olarak, neyin hayalini kurduysa onu ifade etmiştir. Bundan dolayı, böyle bir beklentinin karşılanmamış çocukluk ihtiyaçlarının aşırı telafisi olduğu söylenebilir (Young, 1996). Diğer bir taraftan, Terapist B ve Hasta C arasında görev ve duygusal bağ odaklı terapötik ittifakın değerlendirilmesinde bir benzerlik bulunmaktadır. Hem terapist hem de hasta görev ve duygusal bağ odaklı ittifakı iç içe geçmiş olarak değerlendirmişlerdir. Ancak terapist bu iç içe geçmişliği işlevsiz bir şey olarak tanımlarken, hasta bu görüşe sahip değildir. Arntz (2012) bağımlı kişilik bozukluğuna sahip hastaların söz dinleyen teslimci moda sahip olduğunu bildirmiştir. Bu sebeple, bu tarz hastalar terapistine karşı çıkmaz, öfkelenmez ve terapi sürecindeki problem ve sıkıntıları algılamaz. Ayrıca, Terapist B, görev odaklı ittifak için, bunu küçük bir kesişimle tasvir etmiş olsa da, Süpervizör A'nın da terapist ve hasta ile iç içe geçmiş bir ilişkisinin olduğunu düşünmüştür. Diğer bir taraftan, Terapist B duygusal bağ açısından hasta, terapist ve süpervizör arasında tamamen iç içe geçmiş bir ilişki belirtmiştir. Bunun, Terapist B'nin bağlanma ihtiyacından ve terk edilme ihtimalinden kaçınma amaçlı olduğu varsayılabilir. Buradaki riskli durum, Terapist B ve Hasta C'nin benzer şema ve ebeveyn kökenine sahip olmaları nedeniyle, terapi ilişkisi içerisinde terapist ve hasta birbirlerinin işlevsiz ve sağlıksız örüntüsünü devam ettirmiş ve bu durum da psikoterapinin amaçlarına ulaşmasını engellemiş olabilir (şemaların çakışması, Young, 1996). Diğer bir taraftan, Hasta C, süpervizörü kendinden bağımsız olarak konumlamış çünkü onu tanımadığını ifade etmiştir. Ancak 
süpervizörün Terapist B yoluyla kendi üzerinde bir etkisi olduğunu kabul etmiştir. Bu durumsa Hasta C'nin terk edilme ve reddedilme korkusuyla baş etmek için kullandığ 1 mesafelilik baş etme biçimi ile açıklanabilir. Hasta süpervizörün varlığını kabul etmiş ancak belki de onu tanımadığı ve güvenilir bulmadığı için onu terapist ile ilişkisinde ayrı konumlama ihtiyacı duymuş olabilir. $\mathrm{Bu}$ doğrultuda, Young (1999) da şemaları ile baş etmek için kişilerin bunları aktive eden durumlardan (terk edilmek, reddedilmek veya kabul görmemek) korumak için kişiler arası ilişkilerden kaçındığını ifade etmiştir (mesafelilik/kaçınma baş etme biçimi).

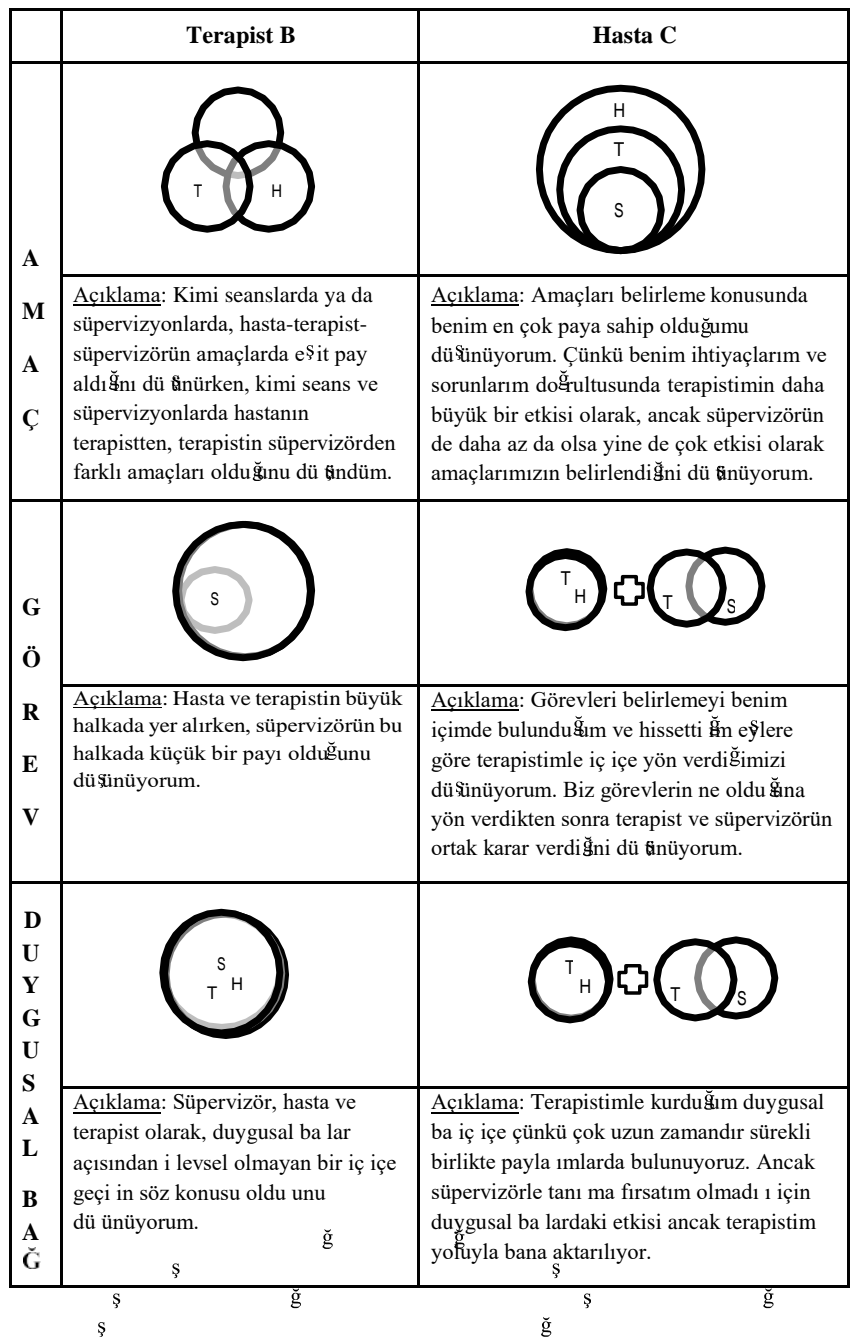

Figür 12. Terapist B ve Hasta C için terapötik ittifakın projektif ölçümleri Not: $\mathrm{S}=$ Süpervizör $\mathrm{A}, \mathrm{T}=$ Terapist $\mathrm{B}, \mathrm{H}=$ Hasta

\section{Genel Tartışma}

Yapılan bu çalışmada her ilişskinin kişinin kendi anne baba örüntüsü, şemaları ve bunlarla baş etme biçimlerinden etkilendiği vurgulanmak istenmiştir. Yukarıda sunulan vaka da bunu destekler niteliktedir. Literatürde, terapötik ittifak ve şemalarla bağlantısı açısından daha önce böyle bir çalışma yapılmamıştır. Ayrıca, terapötik ittifak kavramının karmaşık yapısı ve nicel ölçümlerin kısıtlılığından dolayı, çalışmadan ilişkisel halkalar adlı bir projektif ölçüm aracı da geliştirilmiştir. Bu sebeple bu çalışma literatüre katkısı açısından özgün ve önemlidir. Diğer taraftan, bu çalışmada bazı kısıtlılıklar mevcuttur. Birincisi, süpervizör-terapist ilişkisi haftalık ölçülürken terapist-hasta ilişkisi süpervizyona eş zamanlı ve takiben alınamamıştır. Bu şekilde bir 
çalışma yapılsa süpervizyon sürecinde veya terapi ilişkisinde seans bazlı nelerin ilişkiyi 
etkileyebileceği ile ilgili daha detaylı bilgi sağlanabilir. Ancak pratikte bunu uygulamak çok da kolay olmayacaktır. İkinci olarak, üniversiteye bağlı olarak dönem bazlı devam eden bir terapi sürecinden bilgi toplandığı için kısıtlı görüşme sayısı üzerinden bulgular elde edilmiştir.

Tüm bu kısıtlılıklara rağmen, araştırmada ortaya çıktığı gibi, terapi eğitimi ve uygulamasında sadece bilgi sahibi olmak ve "öğreten” rolünde davranmak terapötik ilişki açısından yeterli değildir. Süpervizör ve terapist ilişkisindeki açık iletişim, öfkelerin, dirençlerin ele alınabilmesi, bilgiyi didaktik sunmaktan daha öğretici ve önemlidir. Zira örnek vakada da görüldüğü gibi ifade edilmeyen duygular, hiçbir problem yokmuş gibi süpervizyon ve terapi süreçlerinin devam etmesine, süpervizyondan yeterince faydalanılamamasına ve terapinin tedavi etmekten çok hastanın sağlıksız döngüsünü sürdürdüğü bir ortama dönüşmesine sebep olabilir. Bu sebeple klinik uygulama ve eğitim süreçlerinde, ilişki kuran ve şimdi ve burada yaşanan ilişkiyi (Bordin, 1979) süpervizyonun ya da terapinin malzemesi olarak kullanabilen akademisyen ve klinisyenlerin sağlıklı ve gerçekçi bir ittifak yakalayabileceği düşünülmektedir. 


\section{Kaynaklar}

Agnew Davies, R., Stiles, W. B., Hardy, G. E., Barkam, M., \& Shapiro, D. A. (1998). Alliance structure assessed by the Agnew Relationship Measure (ARM). British Journal of Clinical Psychology, 37, 155-172.

Allen, J. G., Newsom, G. E., Gabbard, G. O., \& Coyne, L. (1984). Scales to assess the therapeutic alliance from a psychoanalytic perspective. Bulletin of the Menninger Clinic, 48, 383-400.

Anderson, R., \& Anderson, G. (1962). Development of an instrument for measuring rapport. Personal Guidance Journal, 41, 18-24.

Aslan, H., Taymur, İ., \& Türkçapar, M. H. (2012). Evaluation of cognitive schemas based on the presence of anxiety disorder among coronary artery disease patients. Journal of Cognitive-Behavioral Psychotherapy and Research, 1(3), 171-177.

Arntz, A. (2012). Schema Therapy for Cluster C Personality Disorders, in The Wiley-Blackwell Handbook of Schema Therapy: Theory, Research, and Practice (eds M. van Vreeswijk, J. Broersen and M. Nadort), John Wiley \& Sons, Ltd, Chichester, UK.

Aron, L. (1996). A meeting of minds: Mutuality in psychoanalysis. Hillsdale, NJ: Analytic Press.

Bachelor, A. (1987). The counseling evaluation inventory and the counselor rating form: Their relationship to perceived improvement and to each other. PsychologicalReports, 61(2), 567-575.

Baillargeon, P., Cote, R., \& Douville, L. (2012). Resolution process of therapeutic alliance ruptures: A review of the literature. Psychology, 3(12), 1049-1058.

Baranoff, J., Oei, T. P. S., Ho Cho, S., \& Kwon, S.-M. (2006).Factor structure and internal consistency of the Young Schema Questionnaire (Short Form) in Korean and Australian samples. Journal of Affective Disorders, 93, 133-140.

Barrett-Lennard, G. T. (1962). Dimensions of therapist response as casual factors in therapeutic change. Psychological Monographs, 76, 562.

Barrett-Lennard, G. T. (1986). The relationship inventory now: Issues and advances in theory, method and use. In L. S. Greenberg \& W.M. Pinsof (Eds.), The psychotherapeutic process: A research handbook (pp. 439-467). New York and London: Guilford Press.

Beck, A. T., Rush, J. A., Shaw, B. F., \& Emery, G. (1979). Cognitive therapy of depression. New York: Guilford Press.

Bell, D. (1997). Reason and Passion. London

Bell, M., Billington, R., \& Becker, B. (1986). A scale for the assessment of object relations: Reliability, validity, and factorial invariance. Journal of Clinincal Psychology, 42, 733-741.

Berne, E. (1975). What do you say after you say hello? London.

Bordin, E. S. (1979). The generalizability of the psychoanalytic concept of the working alliance. Psychotherapy: Theory, Research, and Practice, 16, 252-260.

Bordin, E. S. (1980). Of human bonds that bind or free. Presidential Address to Tenth Annual Convention of Society for Research on Psychotherapy, Pacific Grove, California.

Bordin, E. (1983). Supervision in counseling: II Contemporary models of supervision: A working alliance based model of supervision. Counseling Psychologist, 11, 35-42.

Bordin, E. S. (1994). Theory and research on the therapeutic working alliance: New directions. In A. O. Horvath \& L. S. Greenberg (Eds.), The working alliance: Theory, research and practice (pp. 13-37). New York: Wiley.

Bowlby, J. (1988). A Secure Base. New York: Basic Books.

Braswell, L., Kendall, P. C., Braith, J., Carey, M. P., \& Vye, C. S. (1985). Involvement in cognitive-behavioral therapy with children: process and its relationship to outcome. 
Cognitive Therapy and Research, 9, 611-630.

Brenner, C. (1979). Working alliance, therapeutic alliance, and transference. Journal of the American Psychoanalytic Association, 27, 136-158.

Cabrera, N. J., Tamis-LeMonda, C. S., Bradley, R. H., Hofferth, S., \& Lamb, M. E. (2000). Fatherhood in the twenty-first century. Child Development, 71, 127-136.

Carson, R. C. (1969). Interaction concepts of personality. Oxford, England: Aldine.

Castonguay, L. G., Constantino, M. J., \& Grosse Holtforth, M. (2006). The working alliance: Where are we and where should we go? Psychotherapy: Theory, Research, Practice, Training, 43(3), 271-279.

Cashdan, S. (1988). Object Relations Therapy. New York: Norton \& Company, s. 53-78.

Constantino, M. J., Arnow, B., Blasey, C., \& Agras, W. S. (2005). The association between patient characteristics and the therapeutic alliance in cognitive-behavioral and interpersonal therapy for bulimia nervosa. Journal of Consulting and Clinical Psychology, 73, 203-211.

Creed, T. A., \& Kendall, P. C. (2005). Therapist alliance - building behavior within a cognitive - behavioral treatment for anxiety in youth. Journal of Consulting and Clinical Psychology, 73(3), 498-505.

Crits-Christoph, P., Baranackie, K., Kurcias, J. S., Beck, A. T., Carroll, K., Perry, K.,Luborsky, L., McLellan, A. T., Woody, G. E., Larry, T., Gallagher, D., \& Zitrin, C. (1991). Meta-analysis of therapist effects in psychotherapy outcome studies. Psychotherapy Research, 1(2), 81-91.

Curtis, H. C. (1979). The concept of the therapeutic alliance: Implications for the "widening scope". Journal of the American Psychoanalytic Association, 27, 159-192.

Derlega, V. J., \& Chaikin, A. L. (2010). Privacy and self-disclosure in social relationships. Journal of Social Issues, 33(3), 102-115.

Di Giuseppe, R., Linscott, J., \& Jilton, R. (1996). Developing the therapeutic alliance in childadolescent psychotherapy. Applied and Preventive Psychology, 5, 85-100.

Driver, C., Martin, E., Banks, M., Mander, G., \& Stewart, J. (2002). Supervising Psychotherapy. London: Sage Publications.

Duan, C., \& Hill, C. E. (1996). The current state of empathy research. Journal of Counseling Psychology, 43, 267-274.

Duan, C., \& Kivlighan, D. M. (2002). Relationships among therapist presession mood, therapist empathy, and session evaluation. Psychotherapy Research, 12(1), 23-37.

Durlak, J. A. (1998). Common risk and protective factors in successful prevention programs. American Journal of Orthopsychiatry, 68(4), 512-520.

Eckler-Hart, A. H. (1987). True and false self in the development of psychotherapist. Psychotherapy: Theory, Research, Practice, Training, 24(4), 683-692.

Efstation, J. F., Patton, M. J., \& Kardash, C. M. (1990). Measuring the working alliance in counselor supervision. Journal of Counseling Psychology, 37, 322-329.

Elliott, R., Watson, J. C., Goldman, R. H., \& Greenberg, L. S. (2004). Learning emotion-focused therapy: The process-experiential approach to change. Washington, DC: American Psychological Association.

Ellis, M. V. (1991). Critical incidents in clinical supervision and in supervisor supervision: Assessing supervisory issues. Journal of Counseling Psychology, 38, 342-349.

Elvins, R., \& Green, J. (2008). The conceptualization and measurement of therapeutic alliance: An empirical review. Clinical Psychology Review, 28, 1167-1187.

Estrada, A., \& Russell, R. (1999). The development of the child psychotherapy process scales (CPPS). Psychotherapy Research, 9, 154-166. 
Eugster, S. L., \&Wampold, B. E. (1996). Systematic effects of participant role on evaluation of the psychotherapy session. Journal of Consulting and Clinical Psychology, 64(5), 1020-1028.

Fleischer, J. A., \& Wissler, A. (1985). The therapist as patient: Special problems and considerations. Psychotherapy, 22(3), 587-594.

Florsheim, P., Shotorbani, S., Guest-Warnick, G., Barrett, T., \& Hwang, W. C. (2000). Role of the working alliance in the treatment of delinquent boys in community based programs. Journal of Clinical Child Psychology, 29, 94-107.

Frank, A. F., \& Gunderson, J. G. (1990). The role of the therapeutic alliance in the treatment of schizophrenia. Relationship to course and outcome. Archives of General Psychiatry, 47, 228-236.

Frank, J. D., \& Frank, J. B. (1991). Persuasion and Healing: A comparative study of psychotherapy, (3rd Ed) Baltimore: Johns Hopkins University Press.

Freud, S. (1912). Standard Ed. The dynamics of transference. In Complete Psychological Works, vol. 12. (pp. 97-108)London: Hogarth Press.

Freud, S. (1913). On beginning the treatment: Further recommendations on the technique of psychoanalysis. Standard edition of the completeworks of Sigmund Freud (pp. 97-108). London: Hogarth Press.

Freud, S. (1966). On the beginning the treatment. In J. Strachey (Ed. and Trans.), The standard edition of the complete psychological works of Sigmund Freud (Vol. 12, pp. 112-144). London: Hogarth Press. (Original work published in 1913 Frieswyk, S. H., Allen, J. G., Colson, D. B., Coyne, L., Gabbard, G. O., Horwitz, L., \& Newsom, G. (1986). Therapeutic alliance: Its place as a process and outcome variable in dynamic psychotherapy research. Journal of Consulting and Clinical Psychology, 54, 32-38.

Friedlander, M. L., Horvath, A. O., Cabero, A., Escudero, V., Heatherington, L., \& Martens, M. P. (2006). System for observing family therapy alliances: a tool for research and practice. Journal of Counseling Psychology, 53(2), 214-224.

Frieswyk, S. H., Allen, J. G., Colson, D. B., Coyne, L., Gabbard, G. O., Horwitz, L., \& Newsom, G. (1986). Therapeutic alliance: Its place as a process and outcome variable in dynamic psychotherapy research. Journal of Consulting and Clinical Psychology, 54, 32-38.

Geller, J., Orlinsky, D., \& Norcross, J. (2005). The psychotherapist's own psychotherapy: Client and clinician perspectives. New York, NY: Oxford University Press.

Gelso, C. J., \& Carter, J. A. (1985). The relationship in counseling and psychotherapy: Components, consequences, and theoretical antecedents. The Counseling Psychologist, 13, 155-244.

Gelso, C. J., \& Carter, J. A. (1994). Components of the psychotherapy relationship: Their interaction and unfolding during treatment. Journal of Counseling Psychology, 41(3), 296-306.

Gelso, C. J., \& Hayes, J. A. (1998). The psychotherapy relationship: Theory, research, and practice. New York: John Wiley.

Glickauf-Hughes, C., \& Mehlman, E. (1995). Narcissistic issues in therapists: Diagnostic and treatment considerations. Psychotherapy: Theory, Research, Practice, Training, 32(2), 213-221.

Gomes-Schwartz, B. (1978). Effective ingredients in psychotherapy: prediction of outcome from process variables. Journal of Consulting and Clinical Psychology, 46, 1023-1035.

Gorin, S. (1993). The prediction of child psychotherapy outcome: factors specific to treatment. Psychotherapy, 30(1), 152-158. 
Gök, A. C. (2012). Associated factors of psychological well-being: Early maladaptive schemas, schema coping processes, and parenting styles. Unpublished master's thesis, Middle East Technical University, Ankara, Turkey.

Green, J., Kroll, L., Imre, D., Frances, F. M., Begum, K., \& Gannon, L. (2001). Health gain and predictors of outcome in inpatient and day patient child psychiatry treatment. Journal of the American Academy of Child and Adolescent Psychiatry, 40, 325-332.

Greenberg, L. S., Rice, L. N., \& Elliott, R. (1993). Facilitating emotional change. New York: Guilford Press.

Greenson, R. R. (1965). The working alliance and the transference neuroses. Psychoanalysis Quarterly, 34, 155-181.

Greenson, R. R. (1967). The technique and practice of psychoanalysis. New York: International Universities Press, Inc.

Gross, J. J. (2002). Emotion regulation: Affective, cognitive, and social consequences. Psychophysiology, 39(3), 281-291.

Gross, J. J., \& John, O. P. (2003). Individual differences in two emotion regulation processes: Implications for affect, relationships, and well-being. Journal of Personality and Social Psychology, 85(2), 348-362.

Hawke, L. D., \& Provencher, M. D. (2012). The Canadian French young schema questionnaire: Confirmatory factor analysis and validation in clinical and nonclinical samples. Canadian Journal of Behavioural Science, 44(1), 40-49.

Hinshelwood, R., Robinson, S. \& Zarate, O. (2006). Introducing Melanie Klein. Cambridge.

Hoffart, A., Sexton, H., Hedley, L. M., Wang, C. E., Holthe, H., Haugum, J. A., Nordahl, H. M., Hovland, O. J., \& Holte, A. (2005). The structure of maladaptive schemas: A confirmatory factor analysis and a psychometric evaluation of factor-derived scales. Cognitive Therapy and Research, 29(6), 627-644.

Holland, J. L. (1997). Making vocational choices (3rd ed.). Odessa, FL: Psychological Assessment Resources

Horvath, A. O., Del Re, A. C., Flückiger, C., \& Symonds, D. (2011). Alliance in individual psychotherapy. Psychotherapy, 48(1), 9-16.

Horvath, A. O., \& Greenberg, L. S. (1989). Development and validation of the Working Alliance Inventory. Journal of Counseling Psychology, 36, 223-233.

Horvath, A. O., \& Symonds, D. B. (1991). Relation between working alliance and outcome in psychotherapy; A meta analysis. Journal of Counseling Psychology, 38(2),139-149.

Hougaard, E. (1994). The therapeutic alliance: A conceptual analysis. Scandinavian Journal of Psychology, 35, 67-85.

Huppert, J. D., Kivity, Y., Barlow, D. H., Gorman, J. M., Shear, K., \& Woods, S. W. (2014). Therapist effects and the outcome-alliance correlation in cognitive behavioral therapy for panic disorder with agoraphobia. Behavior Research and Therapy, 52, 26-34.

Jacobs, C. (1991). Violations of the supervisory relationship: An ethical and educational blind spot. Social Work, 36, 130-135.

Johnson, S. (2001). The therapeutic alliance with early adolescents: Introduction of an instrument. Dissertation Abstracts International, 61(10), 5567B.

Johnson, S., Hogue, A., Diamond, G., Leckrone, J., \& Liddle, H. A. (1998). Scoring manual for the Adolescent Therapeutic Alliance Scale (ATAS).Philadelphia: Temple University Unpublished manuscript.

Jung, C. G. (1976). Analytical psychology: Its theory and practice. London.

Karaosmanoğlu, A., Soygüt, G., \& Kabul, A. (2011). Psychometric properties of the Turkish 
Young Compensation Inventory. Clinical Psychology and Psychotherapy. Published online in Wiley Online Library (wileyonlinelibrary.com). DOI: 10.1002/cpp.78.

Kazdin, A. E., Holland, L., Crowley, M., \& Breton, S. (1997). Barriers to treatment participation scale: Evaluation and validation in the context of child outpatient treatment. Journal of Child Psychology and Psychiatry, 38(8), 1051-1062.

Kazdin, A. E., \& Nock, M. K. (2003). Delineating mechanisms of change in child and adolescent therapy: Methodological issues and research recommendations. Journal of Child Psychology and Psychiatry, 44, 1116-1129.

Kelly, F. D. (1997). The psychological assessment of abused and traumatized children. Mahwah, NJ: Erlbaum.

Kendall, P. C. (1994). Treating anxiety disorders in children: results of a randomised controlled trial. Journal of Consulting and Clinical Psychology, 62, 100-110.

Kiesler, D. J. (1988). Therapeutic metacommunication: Therapist impact disclosure as feedback in psychotherapy. Palo Alto, CA: Consulting Psychologist Press.

Kiesler, D. J. (1996). Contemporary interpersonal theory and research: Personality, psychopathology, and psychotherapy. New York: Wiley.

Kim, S. C., Boren, D. M., \& Solem, S. L. (2001). The Kim alliance scale: Development and preliminary testing. Clinical Nursing Research, 10, 314-331.

Klein, M. (1932). The psychoanalysis of children. London: Hogarth Press.

Klein, M. (1952). "Some Theoretical Conclusions Regarding the Emotional Life of the Infant" in Developments in Psychoanalysis, London: Hogarth Press.

Köse, B. (2009). Associations of psychological well-being with early maladaptive schemas and self-construals. Unpublished master's thesis. Middle East Technical University, Ankara, Turkey.

Kroll, L., \& Green, J. M. (1997). Therapeutic alliance in inpatient child psychiatry. Development and initial validation of the family engagement questionnaire. Clinical Child Psychology and Psychiatry, 2(3), 431-447.

Ladany, N., Constantine, M. G., Miller, K., Erickson, C. D., \& Muse-Burke, J. L. (2000). Supervisor countertransference: A qualitative investigation into its identification and description, Journal of Counseling Psychology, 47(1), 102-115.

Lamb, M. E. (1975). Fathers: Forgotten contributors to child development. Human Development, 18(4), 245-266.

Lamb, M. E., Pleck, J. H., \& Levine, J. A. (1985). The role of the father in child development. Advances in Clinical Child Psychology, 8, 229-266.

Leary, T. (1957). Interpersonal diagnosis of personality. New York: Ronald Press.

Lee, C. W., Taylor, G., \& Dunn, J. (1999). Factor structure of the schema questionnaire in a large clinical sample. Cognitive Therapy and Research, 23(4), 441-451.

Levenson, H. (1995). Time-limited dynamic psychotherapy: A guide to clinical practice. New York: Basic Books.

Linden, J., Stone, J., \& Shertzer, B. (1965). Development and evaluation of an inventory for rating counseling. Personnel and Guidance Journal, 44, 267-276.

Luborsky, L. (1976). Helping alliances in psychotherapy. In J. L. Claghorn (Ed.), Successful psychotherapy (pp. 92-116). New York: Brunner/Mazel.

Luborsky, L. (1984). Principles of Psychodynamic Psychotherapy. New York: Basic Books.

Luborsky, L., Chandler, M. Auerbach, A. H., Cohen, J., \& Bachrach, H. M. (1971). Factors influencing the outcome of psychotherapy: A review of quantitative research. Psychological Bulletin, 75(3), 145-185. 
Luborsky, L., Singer, B., \& Luborsky, L. (1975). Comparative studies of psychotherapies: Is it true that "Everyone has won and all must have prizes?" Archives of General Psychiatry, 32, 995-1008.

Ludwig, A. M. (1983). The psychobiological functions of dissociation. American Journal of Clinical Hypnosis, 26(2), 93-99.

Macran, S., Stiles, W. B., \& Smith, J. A. (1999). How does personal therapy affect therapist's practice. Journal of Counseling Psychology, 46, 419-431.

Marmar, C. R., Horowitz, M. J., Weiss, D. S., \& Marziali, E. (1986). The development of the therapeutic alliance rating system. In L. S. Greenberg \&W.M. Pinsof (Eds.), The psychotherapeutic process: A research handbook (pp. 367-390). New York and London: Guilford Press.

Marmarosh, C. L., Gelso, C. J., Markin, R. D., Majors, R., Mallery, C., \& Choi, J. (2009). The real relationship in psychotherapy: Relationships to adult attachments, working alliance, transference, and therapy outcome. Journal of Counseling Psychology, 56(3), 337-350.

Marziali, E., Marmar, C., \& Krupnick, J. (1981). Therapeutic alliance scales: Development and relationship to psychotherapy outcome. Journal of Nervous and Mental Disease, 172, 417-423.

Mayers, D., \& Hayes, J. A. (2006). Effects of therapist general self-disclosure and countertransference disclosure on ratings of the therapist and session. Psychotherapy: Theory, Research, Practice, Training, 43(2), 173-185.

McCarthy, W.C., \& Frieze, I.H. (1999). Negative aspects of therapy: Client perceptions of therapists' social influence, burnout, and quality of care. Journal of Social Issues, 55(1), 33-50.

McCoy Lynch, M. (2012). Factors influencing successful psychotherapy outcomes. Master of Social Work Clinical Research Papers, 57.

McGuire-Snieckus, R., McCabe, R., Catty, J., Hanson, L., \& Priebe, S. (2007). A new scale to assess the therapeutic relationship in community mental health: STAR. Psychological Medicine, 37, 85-95.

McLeod, B. D., \& Weisz, J. R. (2005). The therapy process observational coding system-alliance scale: Measure characteristics and prediction of outcome in usual clinical practice. Journal of Consulting and Clinical Psychology, 73(2), 323-333.

Mitchell, S. A. (1988). Relational concepts in psychoanalysis. Cambridge, MA: Harvard University Press.

Mitchell, S. A. (1993). Hope and dread in psychoanalysis. New York: Basic Books.

Molinaro (1998). Development and validation of a new measure of therapist focus on alliance related content. Dissertation Abstracts International, 58(10), 5651B.

Nissen-Lie, H. A., \& Havik, O. E. (2013). The contribution of the quality of therapists's personal lives to the development of the working alliance. Journal of Counseling Psychology, 60(4), 483-495.

Orlinsky, D. E., \& Howard, K. I. (1966). Therapy Session Report (Form T and Form P). Chicago: Institute of Juvenile Research.

Orlinsky, D. E., \& Howard, K. I. (1975). Varieties of Psychotherapeutic Experience: Multivariate Analysis of Patients' and Therapists' Reports. New York: Teachers College Press.

Özbaş, A. A., Sayın, A., \& Coşar, B. (2012). Üniversite sinavina hazirlanan öğrencilerde sinav öncesi anksiyete düzeyi ile erken dönem uyumsuz şema iliş̧ilerinin incelenmesi. Bilişsel Davranışçı Psikoterapi ve Araştırmalar Dergisi, 1, 81-89.

Patton, M. J. (1984). Managing social interaction in counseling: A contribution from the 
philosophy of science. Journal of Counseling Psychology, 31, 442-456.

Pinsof, W.M. (1999). Family Therapy Alliance Scale-Revised. Unpublished Manuscript. The Family Institute, Evanston IL.

Priebe, S., \& Gruyters, T. (1993). Role of the helping alliance in psychiatric community care: A prospective study. Journal of Nervous and Mental Disease, 181(9), 553-557.

Priebe, S., \& McCabe, R. (2006). The therapeutic relationship in psychiatric settings. Acta Psychiatrica Scandinavica, 113(429), 69-72.

Prochaska, J. O., \& Norcross, J. C. (2006). Systems of psychotherapy: A transtheoretical analysis (Sixth Edition). Pacific Grove, CA: Brooks-Cole.

Prochaska, J. O., \& DiClemente C. C. (1986). Toward a comprehensive model of change. Addictive Behaviors: Processes of Change. W. R. Miller and N. Heather. New York; Plenum Press: 3-27.

Richards, J. M., \& Gross, J. J. (1999). Composure at any cost? The cognitive consequences of emotion suppression. Personality and Social Psychology Bulletin, 25(8), 1033-1044.

Rogers, C. R. (1957). The necessary and sufficient conditions of therapeutic personality change. Journal of Consulting Psychology, 21, 95-103.

Rogers, C. R. (1965). Client-centered therapy: its current practice, implications, and theory. Boston: Houghton Mifflin.

Rosenberger, E. W., \& Hayes, J. A. (2002). Origins, consequences, and management of countertransference: A case study. Journal of Counseling Psychology, 49(2), 221-232.

Rosenfeld, H. W. (2010). Addressing personal issues in supervision: Positive and negative experiences of supervisees. Dissertation Abstracts International: Section B: The Sciences and Engineering, 71(4-B), 2699.

Russell, A. \& Saebel, J. (1997). Mother-son, mother-daughter, father-son, and father-daughter: Are they distinct relationships? Developmental Review, 17, 111-147.

Saariaho, T., Saariaho, A., Karila, I., \& Joukama, M. (2009). The psychometric properties of the Finnish Young Schema Questionnaire in chronic pain patients and a non-clinical sample. Journal of Behavior Therapy and Experimental Psychiatry, 40, 158-168.

Safran, J. D. (1993). Breaches in the therapeutic alliance: An arena for negotiating authentic relatedness. Psychotherapy, 30(1), 11-24.

Safran, J. D., \& Muran, J. C. (2000). Negotiating the therapeutic alliance: A relational treatment guide. New York: Guilford Press.

Safran, J. D., \& Segal, Z. (1996). Interpersonal process in cognitive therapy. Northvale, New Jersey: Jason Aronson Inc.

Sarıtaş, D. (2007). The effects of maternal acceptance-rejection on psychological distress of adolescents: The mediator roles of early maladaptive schemas. Unpublished mater's thesis, Middle East Technical University, Ankara, Turkey.

Sarıtaş, D., \& Gençöz, T. (2011). Psychometric properties of "Young Schema Questionnaire-Short Form 3" in a Turkish adolescent sample. Journal of Cognitive Behavioral Psychotherapies, 11(1), 83-96.

Sarlin, N.S. (1992). Working relationships in the treatment of adolescent inpatients: Early treatment predictors and associations with outcome. Dissertation Abstracts International.

Saunders, S. M., Howard, K. I., \& Orlinsky, D. E. (1989). The therapeutic bond scales: Psychometric characteristics and relationship to treatment effectiveness. Psychological assessment: A Journal of Consulting and Clinical Psychology, 1, 323-330.

Scott, J., Teasdale, J. D., Paykel, E. S., Johnson, A. L., Abbott, R., Hayhurst, H,. Moore, R., \& Garland, A. (2000). Effects of cognitive therapy on psychological symptoms and social 
functioning in residual depression. The British Journal of Psychiatry, 177, 440-446. Seligman, M. E. P., Reivich, K., Jaycox, L., \& Gillham, J. (1995). The optimistic child. US: Houghton, Mifflin and Company.

Shirk, S. R., \& Saiz, C. C. (1992). Clinical, empirical and developmental perspectives on the therapeutic relationship in child psychotherapy. Development and Psychopathology, 4 , $713-728$.

Sidney, J. B. (2013). The patient's contribution to the therapeutic process: A Rogerian-psychodynamic perspective. Psychoanalytic Psychology, 30(2), 139-166.

Smith, M. L., \& Glass, G. V. (1977). Meta-analysis of psychotherapy outcome studies. American Psychologist, 32, 752-760.

Smith-Acuna, S., Durlak, J., \& Kaspar, C. (1991). Development of child psychotherapy measures. Journal of Clinical Child Psychology, 20, 126-131.

Solano, C. H. Batten, P. G., \& Parish, E. A. (1982). Loneliness and patterns of self-disclosure. Journal of Personality and Social Psychology, 43(3), 524-531.

Soygüt, G., Karaosmanoğlu, H.A., \& Çakır, Z. (2008a). Early stage maladaptic schemas: An examination of the psychometric properties of the Young Parenting Inventory. Turkish Psychological Articles, 11(22), 34-36.

Soygüt, G., Karaosmanoğlu, A. ve Çakır, Z. (2009). Erken Dönem Uyumsuz Şemaların Değerlendirilmesi: Young Şema Ölçeği Kısa Form-3'ün Psikometrik Özelliklerine İlişkin Bir İnceleme. Türk Psikiyatri Dergisi, 20(1), 75-84.

Stallard, P. (2007). Early maladaptive schemas in children: Stability and differences between a community and a clinic referred sample. Clinical Psychology and Psychotherapy, 14, $10-18$.

Sterba, R. (1934). The fate of the ego in analytic therapy. International Journal of Psychoanalysis, 15, 117-126.

Stricker, G. \& Healey, B. J. (1990). Projective assessment of object relations: A review of the empirical literature. Psychological Assessment, 2, 219-230.

Strong, S. R. (1968). Counseling: An interpersonal influence process. Journal of Counseling Psychology, 15, 215-224.

Sullivan, H. S. (1953). The interpersonal theory of psychiatry. New York: Norton.

Svensson, B., \& Hansson, L. (1999). Relationships among patient and therapist ratings of therapeutic alliance and patient assessment of therapeutic process: A study of cognitive therapy with long term mentally ill patients. Journal of Nervous and Mental Disease, 87(9), 579-585.

Symonds, D., \& Horvath, A. O. (2004). Optimising the alliance in couple therapy. Family Process, 43(4), 443-455.

Taber, B. J., Leibert, T. W., \& Agaskar, V. R. (2011). Relationships among client-therapist personality congruence, working alliance, and therapeutic outcome. Psychotherapy, 48(4), 376-380.

Teitelbaum, S. H. (1990). Supertransference: The role of the supervisor's blind spots. Psychoanalytic Psychology, 7, 243-258.

Tracey, T. J., \& Kokotovic, A. M. (1989). Factor structure of the Working Alliance Inventory. Psychological Assessment, 1, 207-210.

Ünal, B. (2012). Early maladaptıve schemas and well-being: Importance of parenting styles and other psychological resources. Unpublished master's thesis, Middle East Technical University, Ankara, Turkey.

Wampold, B. E., \& Brown, G. S. (2005). Estimating variability in outcomes attributable to 
therapists: A naturalistic study of outcomes in managed care. Journal of Consulting and Clinical Psychology, 73(5), 914-923.

Wachtel, P.L. (2008). Relational theory and the practice of psychotherapy. New York: Guilford Press.

Winnicott, D. W. (1965). The Family and Individual Development. London: Tavistock.

Young, J. (1994). Young Parenting Inventory. Unpublisehed report.

Young, J. (1995). Young Compensation Inventory. New York: Cognitive Therapy Center of New York.

Young, J. E. (1999). Cognitive therapy for personality disorders: A schema-focused approach. (3rd ed.) Sarasota FL: Professional Resource Press.

Young, J. E., \& Brown, G. (1990). Young Schema Questionnaire: Special Edition. New York: Schema Therapy Institute.

Young J. E., Klosko J. S., \& Weishaar, M. E. (2003). Schema therapy: A practitioner's guide. New York. The Guilford Pres.

Young, J., \& Rygh, J. (1994). Young-Rygh Avoidance Inventory. New York: Cognitive Therapy Center of New York.

Zetzel, E. (1956). Current concepts of transference. International Journal of Psychoanalysis, 37, 369-375. 


\section{Summary:}

\section{Therapeutic Alliance among Supervisor, Therapist, and Client Trio and Schema Concept as} the Affecting Factor: A Case Analysis

In the present study, the aim was to measure the effects of Young schema domains, Young maladaptive coping styles, and Young parenting styles on working alliance among Supervisor A, Therapist B, and Client C. For the case study, participants were a supervisor (clinical psychology doctorate student), a therapist (clinical psychology master student), and a client (applicant to AYNA Psychotherapy Unit). In order to measure working alliance, two types of measurement, one qualitative (open ended questions and relational circles, which were developed by the researcher) and one quantitative scale (Working alliance inventory/supervisor-therapist and therapist-client forms) were used. According to the results, a relation between Young schemas, parenting styles, and coping styles and working alliance was found among Supervisor A, Therapist B, and Client C. Associations were discussed in line with Schema Theory.

Keywords: Schema Theory, Working Alliance, Supervision, Psychotherapy 